\title{
Recycle of lodine-Loaded Silver Mordenite by Hydrogen Reduction
}

L. L. Burger

R. D. Scheele

November 1982

Prepared for the U.S. Department of Energy under Contract DE-AC06-76RLO 1830

Pacific Northwest Laboratory Operated for the U.S. Department of Energy by Battelle Memorial Institute 


\title{
DISCLAIMER
}

This report was prepared as an account of work sponsored by an agency of the United States Government. Neither the United States Government nor any agency thereof, nor any of their employees, makes any warranty, express or implied, or assumes any legal liability or responsibility for the accuracy, completeness, or usefulness of any information, apparatus, product, or process disclosed, or represents that its use would not infringe privately owned rights. Reference herein to any specific commercial product, process, or service by trade name, trademark, manufacturer, or otherwise, does not necessarily constitute or imply its endorsement, recommendation, or favoring by the United States Government or any agency thereof. The views and opinions of authors expressed herein do not necessarily state or reflect those of the United States Government or any agency thereof.

\author{
PACIFIC NORTHWEST LABORATORY \\ operated by \\ BATTELLE \\ for the \\ UNITED STATES DEPARTMENT OF ENERGY \\ under Contract DE-AC06-76RLO 1830
}

\begin{tabular}{|c|c|}
\hline \multicolumn{2}{|c|}{$\begin{array}{c}\text { Printed in the United States of America } \\
\text { Available from } \\
\text { National Technical Information Service } \\
\text { United States Department of Commerce } \\
5285 \text { Port Royal Road } \\
\text { Springfield, Virginia } 22151\end{array}$} \\
\hline \multicolumn{2}{|c|}{$\begin{array}{l}\text { NTIS Price Codes } \\
\text { Microfiche A01 }\end{array}$} \\
\hline \multicolumn{2}{|c|}{ Printed Copy } \\
\hline Pages & $\begin{array}{l}\text { Price } \\
\text { Codes }\end{array}$ \\
\hline $001-025$ & $\mathrm{~A} 02$ \\
\hline $026-050$ & $\mathrm{AOB}$ \\
\hline $051-075$ & $A 04$ \\
\hline $076-100$ & A05 \\
\hline $10 \div-125$ & A06 \\
\hline $126-150$ & $A 07$ \\
\hline $151-175$ & AOB \\
\hline $176-200$ & $A 09$ \\
\hline $201-225$ & $\wedge 010$ \\
\hline $226-250$ & A011 \\
\hline $251-275$ & A 012 \\
\hline $276-300$ & A013 \\
\hline
\end{tabular}


L. L. Burger
R. D. Scheele

November 1982

Prepared for the U.S. Department of Energy under Contract DE-AC06-76RLO-1830

Pacific Northwest Laboratory

Richland, Washington 99352 

SUMMARY

In 1977 and 1978, workers at Idaho National Engineering Laboratory (INEL) developed and tested a process for the regeneration and reuse of silver mordenite, AgZ, used to trap iodine from the dissolver off-gas stream of a nuclear fuel reprocessing plant. We were requested by the Airborne Waste Management Program Office of the Department of Energy to perform a confirmatory recycle study using repeated loadings at about $150^{\circ} \mathrm{C}$ with elemental iodine, each followed by a drying step at $300^{\circ} \mathrm{C}$, then by iodine removal using elemental hydrogen at $500^{\circ} \mathrm{C}$.

The results of our study show that AgZ can be recycled. There was considerable difficulty in stripping the iodine at $500^{\circ} \mathrm{C}$; however, this step went reasonably well at $550^{\circ} \mathrm{C}$ or slightly higher, with no apparent loss in the iodine-loading capacity of the AgZ.

Large releases of elemental iodine occurred during the drying stage and the early part of the stripping stage. Lead zeolite, which was employed in the original design to trap the HI produced, is ineffective in removal of $I_{2}$. The process needs modification to handle the iodine.

Severe corrosion of the stainless steel components of the system resulted from the $\mathrm{HI}-\mathrm{I}_{2}-\mathrm{H}_{2} \mathrm{O}$ mixture. Mone ${ }^{\circledast}$ or other halogen-resistant materials need to be examined for this application.

Because of difficulty with the stripping stage and with corrosion, the experiments were terminated after 12 cycles. Thus, the maximum lifetime (cycles) of recycled AgZ has not been determined.

Mechanistic studies of iodine retention by silver zeolites and of the behavior of silver atoms on the reduction stage would be of assistance in optimizing silver mordenite recycle.

बTrademark of Huntington Alloys, Inc., Huntington, West Virginia. 


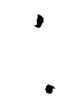




\section{CONTENTS}

\begin{tabular}{|c|c|c|c|c|c|c|c|c|c|c|c|c|}
\hline SUMMARY & - & - & - & - & - & - & - & - & - & - & - & ii \\
\hline INTRODUCTION & - & - & - & - & - & - & - & - & - & - & - & 1 \\
\hline CONCLUSIONS AND & \multicolumn{4}{|c|}{ RECOMMENDATIONS } & - & - & - & - & - & - & - & 3 \\
\hline EXPERIMENTAL EL & EMENTS & & . & . & - & - & - & - & - & - & - & 5 \\
\hline RESULTS & . & . & . & • & - & - & - & - & . & - & - & 9 \\
\hline DISCUSSION & - & - & - & - & - & - & - & - & - & - & - & 15 \\
\hline ACKNOWLEDGMENTS & - & - & - & - & - & - & - & - & - & - & - & 21 \\
\hline REF ERENCES & • & - & - & - & - & - & - & - & - & - & - & 23 \\
\hline APPENDIX & . & . & . & - & - & - & - & - & - & - & . & A.1 \\
\hline
\end{tabular}




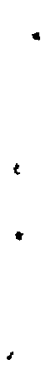


FIGURES

1 Iodine Loading and Stripping Experimental Apparatus $\quad$ - $\quad 6$

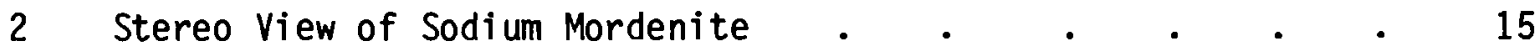

3 Scanning Electron Micrograph of $100 \mathrm{mg} \mathrm{I} / \mathrm{g} \mathrm{Ag}^{\circ} \mathrm{Z}$. $\quad$. 17

\section{TABLES}

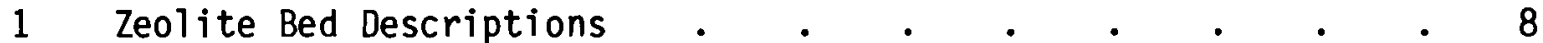

2 Experimental Operating Conditions for $\mathrm{AgZ}$ and

$\mathrm{PbX}$ Beds During Iodine Loading and AgZ Recycle . . $\quad$. 8

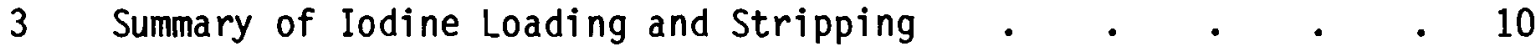

A.1 Iodine-Loading Characteristics for AgZ Bed 1, Cycle 1, Loading Stage

A.2 Iodine-Loading Characteristics for AgZ Bed 1, Cycle 1, Drying Stage

A.3 Iodine-Loading Characteristics for AgZ Bed 1, Cycle 2, Loading Stage

A.4 Iodine-Loading Characteristics for AgZ Bed 2, Cycle 1, Loading Stage

A.5 Iodine-Loading Charaacteristics for AgZ Bed 2, Cycle 1, Drying Stage

A.6 Iodine-Loading Characteristics for AgZ Bed 2, Cycle 2, Loading Stage

A.7 Iodine-Loading Characteristics for AgZ Bed 2, Cycle 2, Drying Stage

A.8 Iodine-Loading Characteristics for AgZ Bed 2, Cycle 2, Stripping Stage

A.9 Iodine-Loading Characteristics for AgZ Bed 2, Cycle 3, Loading Stage

A.10 Iodine-Loading Characteristics for AgZ Bed 2, Cycle 3, Drying Stage . . . . . . . . . . A.6

A.11 Iodine-Loading Characteristics for AgZ Bed 2, Cycle 3, Stripping Stage

A.12 Iodine-Loading Characteristics for AgZ Bed 2, Cycle 4, Loading Stage 
TABLES (Continued)

A.13 Iodine-Loading Characteristics for AgZ Bed 2, Cycle 4, Drying Stage

A.14 Iodine-Loading Characteristics for AgZ Bed 2, Cycle 4, Stripping Stage

A.15 Iodine-Loading Characteristics for AgZ Bed 2, Cycle 5, Loading Stage

A.16 Iodine-Loading Characteristics for AgZ Bed 2, Cycle 5, Drying Stage . . . . . . . . A.10

A.17 Iodine-Loading Characteristics for AgZ Bed 2, Cycle 5, Stripping Stage

A.18 Iodine-Loading Characteristics for AgZ Bed 2, Cycle 6, Loading Stage

A.19 Iodine-Loading Characteristics for AgZ Bed 2, Cycle 6, Drying Stage

A.20 Iodine-Loading Characteristics for AgZ Bed 2, Cycle 6, Stripping Stage

A.21 Iodine-Loading Characteristics for AgZ Bed 2, Cycle 7, Loading Stage

A.22 Iodine-Loading Characteristics for AgZ Bed 2, Cycle 7, Drying Stage

A.23 Iodine-Loading Characteristics for AgZ Bed 2, Cycle 7, Stripping Stage \#1

A.24 Iodine-Loading Characteristics for AgZ Bed 2, Cycle 7, Stripping Stage \#2

A.25 Iodine-Loading Characteristics for AgZ Bed 2, Cycle 8, Loading Stage

A.26 Iodine-Loading Characteristics for AgZ Bed 2, Cycle 8, Drying Stage

A.27 Iodine-Loading Characteristics for AgZ Bed 2, Cycle 8, Stripping Stage

A.28 Iodine-Loading Characteristics for AgZ Bed 2, Cycle 9, Loading Stage

A.29 Iodine-Loading Characteristics for AgZ Bed 2, Cycle 9, Drying Stage 


\section{TABLES (Continued)}

A.30 Iodine-Loading Characteristics for AgZ Bed 2, Cycle 9, Stripping Stage

A.31 Iodine-Loading Characteristics for AgZ Bed 2, Cycle 10, Loading Stage

A.32 Iodine-Loading Characteristics for AgZ Bed 2, Cycle 10, Drying Stage

A.33 Iodine-Loading Characteristics for AgZ Bed 2, Cycle 10, Stripping Stage

A.34 Iodine-Loading Characteristics for AgZ Bed 2, Cycle 11, Loading Stage

A.35 Iodine-Loading Characteristics for AgZ Bed 2, Cycle 11, Drying Stage \#1

A.36 Iodine-Loading Characteristics for AgZ Bed 2, Cycle 11, Stripping Stage \#1

A.37 Iodine-Loading Characteristics for AgZ Bed 2, Cycle 11, Drying Stage \#2

A.38 Iodine-Loading Characteristics for AgZ Bed 2, Cycle 11, Stripping Stage \#2

A.39 Iodine-Loading Characteristics for AgZ Bed 2, Cycle 11, Stripping Stage \#3

A.40 Iodine-Loading Characteristics for AgZ Bed 2, Cycle 12, Loading Stage

A.41 Iodine-Loading Characteristics for AgZ Bed 2, Cycle 12, Drying Stage

A.42 Iodine-Loading Characteristics for AgZ Bed 2, Cycle 12, Stripping Stage \#1

A.43 Iodine-Loading Characteristics for AgZ Bed 2, Cycle 12, Stripping Stage \#2

A.44 Iodine-Loading Characteristics for AgZ Bed 2, Cycle 12, Stripping Stage \#3

A.45 Iodine-Loading Characteristics for AgZ, Bed 2, Cycle 12, Stripping Stage \#4 


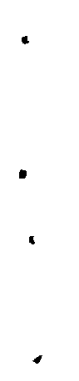




\section{INTRODUCTION}

Silver-exchanged zeolites, especially silver mordenite, AgZ, have received considerable attention as agents for removal of radioactive iodine species from gas streams. Although it is marginally suitable as a final disposal form (Burger, Scheele and Wiemers 1981), the value of silver has prompted some effort in recycling the silver mordenite by removal of the iodine. Workers at Idaho National Engineering Laboratory (INEL) (Thomas et al. 1977; Murphy, Staples and Thomas 1977) carried out a series of iodine loadings followed by removal by hydrogen. This work was summarized by Thomas and a conceptual process described (Thomas, Staples and Murphy 1978). With an iodine loading corresponding to about $34 \%$ silver utilization, no decrease in capacity was observed over 5 cycles, a 20\% decrease after 13 cycles. By contrast, silver faujasite, AgX, was noticeably degraded after 5 cycles.

As part of our iodine fixation program, we were asked to carry out a confirmatory recycle test using repeated loadings with elemental iodine, each followed first by a drying step, then by iodine removal using elemental hydrogen. This study is presented here. 



\section{CONCLUSIONS AND RECOMMENDATIONS}

Based on our studies of hydrogen regeneration of iodine-loaded silver mordenite (AgZI), we conclude that silver mordenite ( $A g Z$ ) can be reused for iodine capture from a nuclear fuels reprocessing plant's dissolver off-gas stream. For employment of this process, provision must be made for control of elemental iodine released during the drying and stripping stages; also, materials of construction resistant to the $\mathrm{I}_{2}-\mathrm{HI}-\mathrm{H}_{2} \mathrm{O}$ triad must be determined. We believe that mechanistic studies of the iodine capture and stripping processes are very desirable.

In this study, a $320 \mathrm{~g} \mathrm{AgZ}$ bed $(5 \mathrm{~cm}$ dia. $\times 20 \mathrm{~cm}$ ) was loaded and stripped a total of 12 times. The loading levels and bed behavior on drying and stripping varied with each cycle. The iodine loaded per cycle ranged from 60 to $125 \mathrm{mg} \mathrm{I/g} \mathrm{AgZ,} \mathrm{with} \mathrm{an} \mathrm{average} \mathrm{of} 86 \mathrm{mg} \mathrm{I/g} \mathrm{AgZ;} \mathrm{the} \mathrm{total} \mathrm{iodine}$ loadings ranged from 96 to 200, with an average of $144 \mathrm{mg} \mathrm{I/g} \mathrm{AgZ.} \mathrm{The} \mathrm{maxi-}$ mum theoretical loading (based on the silver content of the zeolite) is $225 \mathrm{mg}$ $\mathrm{I} / \mathrm{g} \mathrm{AgZ}$.

During drying and the early stages of hydrogen treatment, considerable elemental iodine was released from the bed. This $\mathrm{I}_{2}$ was not captured by the lead zeolite $X(P b X)$ bed; it either circulated throughout the recycle system or was deposited onto the AgZ bed or various components of the system. Iodine in the system loop caused occasional plugging of valves and enhanced the corrosion of the stainless steel components of the system.

Success in removing the iodine from the AgZ varied from cycle to cycle. Beginning with the 5 th cycle, we were unable to remove all the loaded iodine, which subsequently accumulated with each successive cycle until run 11. After a multiple stripping of loading 11 , we had reduced the iodine content from 140 $\mathrm{mg} \mathrm{I/g} \mathrm{AgZ} \mathrm{(after} \mathrm{cycle} \mathrm{10)} \mathrm{to} 21 \mathrm{mg} \mathrm{I/g} \mathrm{AgZ.} \mathrm{Upon} \mathrm{closer} \mathrm{analysis} \mathrm{of} \mathrm{the}$ different cycles, it appears that a temperature of $550^{\circ} \mathrm{C}$ or greater is required to effectively strip the iodine.

Corrosion of the stainless steel components in our system was a major problem. In particular, the stainless steel bellows of the recirculating pump 
failed frequently from corrosion. If recycling is considered further, then other materials of construction, such as Mone1 need to be considered.

The release of $\mathrm{I}_{2}$ upon heating suggests an alternative process using air or $\mathrm{N}_{2}$ and heating at $400-600^{\circ} \mathrm{C}$ to remove the $60-80 \%$ of the iodine which is not strongly bound. The released iodine could then be captured in an aqueous hydroxide trap.

Our brief examination of the chemistry of iodine on silver zeolites shows gaps in the basic information. Of importance to the present study are such things as the bonding of molecular iodine in the zeolite and the location of silver atoms and their migration during reduction.

${ }^{\circledR}$ Trademark of Huntington Alloys, Inc., Huntington, West Virginia. 


\section{EXPERIMENTAL ELEMENTS}

The loading and stripping apparatus used is diagrammed in Figure 1. The containers for the AgZ (silver mordenite) and $\mathrm{PbX}$ (lead zeolite $\mathrm{X}$ ) were constructed of $50 \mathrm{~mm}$ I.D. quartz and borosilicate glass, respectively. Each was heated with a large tube furnace. Three thermocouple wells were evenly spaced over the $20 \mathrm{~cm}$, packed, AgZ bed length. The iodine generator and associated ports, as well as the condensers for water removal, were borosilicate glass. All other components, including the $13 \mathrm{~mm}$ connecting lines, were stainless stee1, predominately type 316. A Datatest Corporation(a) Model 301 oxygen detector was employed during the drying and hydrogenation stages. It registered $0-25 \%$ with a logarithmic response curve giving high accuracy at 10 w concentrations.

The iodine generator used the $\mathrm{I}^{-}+\mathrm{IO}_{3}^{-}$reaction in the presence of $4 \frac{\mathrm{M}}{4}$ $\mathrm{H}_{2} \mathrm{SO}_{4}$. Potassium iodide traced with ${ }^{131_{1}}$ was pumped into the $\mathrm{IO}_{3}^{-}-\mathrm{H}_{2} \mathrm{SO}_{4}$ solution with the metering pump, Pump No. 1 , and the resulting $I_{2}$ was swept into the AgZ bed with warmed air. The 1 liter hold-up bulb was operated with a residence time calculated to convert approximately $50 \%$ of the $\mathrm{NO}$ to $\mathrm{NO}_{2}$.

A cycle consisted of 4 stages: pretreatment, iodine loading, drying, and hydrogen reduction or stripping. Pretreatment consisted of a short treatment with room air at $150^{\circ} \mathrm{C}$ to re-equilibrate the $\mathrm{AgZ}$ with respect to moisture.

For the loading stage, breakthrough was best determined by using a layer of $\mathrm{AgX}$ in a tube at the outlet, point a. Experience showed that the AgX turned yellow when the decontamination factor (DF) dropped below about $10^{3}$. The progress was also monitored by observing the color of the AgZ bed. The loading distribution on the AgZ bed was then determined by making a vertical scan with a scintillation counter. Eight regions were counted over the $20 \mathrm{~cm}$ bed length using an $8 \mathrm{~mm}$ slit window in a $2 \mathrm{~cm}$ thick lead shield. A similar scan was made after each of the succeeding stages.

Following the loading stage, the Agz bed temperature was raised to $300^{\circ} \mathrm{C}$, and argon or $6 \% \mathrm{H}_{2}$ in helium was passed through the bed to remove excess water from the zeolite. For this operation, the system was closed except for a

(a) Datatest Corporation, Levittown, Pennsylvania. 

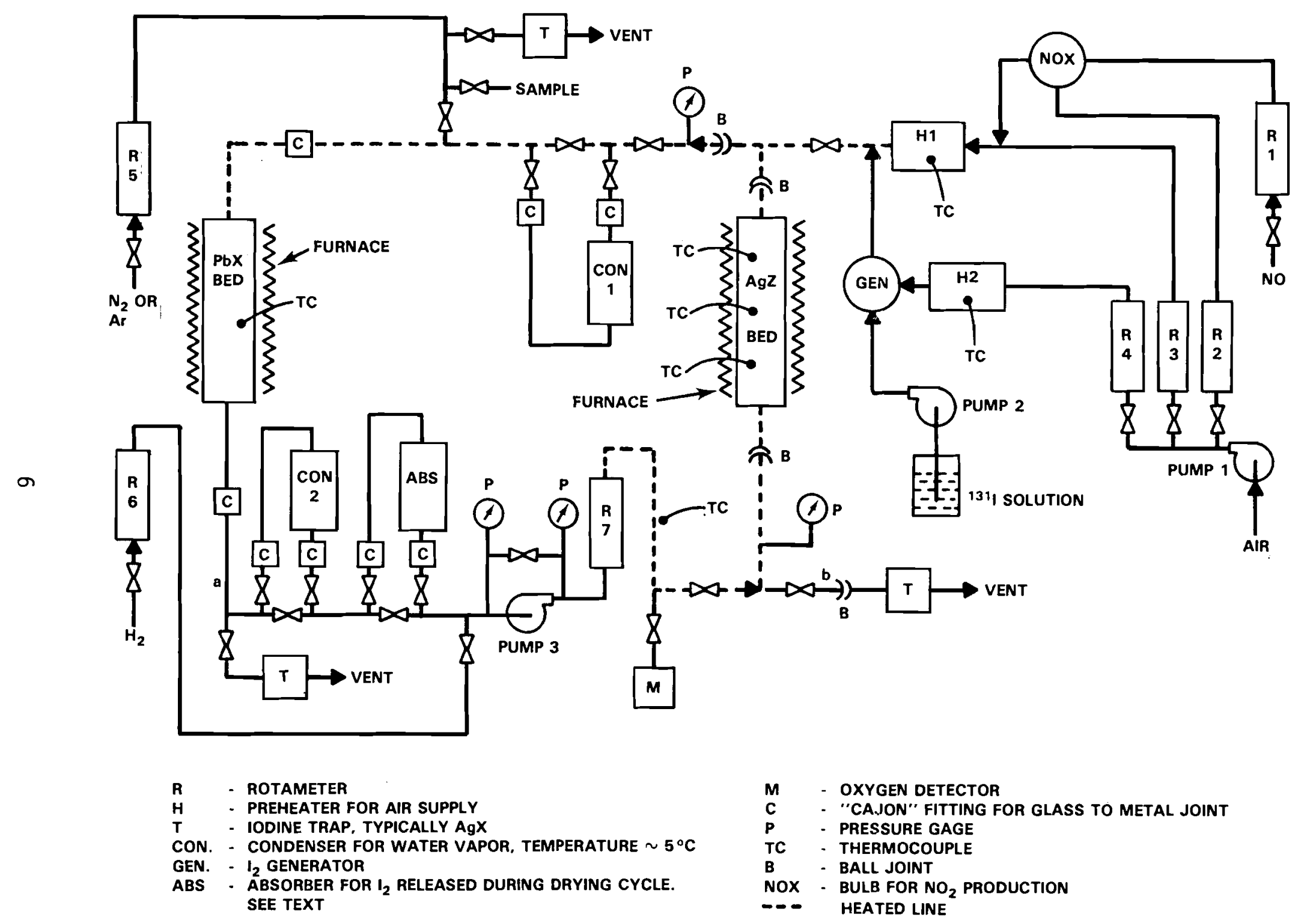

FIGURE 1. Iodine Loading and Stripping Experimental Apparatus 
small bleed stream of argon. The gas stream passed through the first condenser for the first hour or two, and most of the water was removed.

Unfortunately, considerable $I_{2}$ was released from the AgZ bed during drying. This came as no surprise, for our previous studies had shown that a large fraction of the iodine loaded beyond about 25-30\% theoretical silver utilization is loosely bound in molecular form and easily removed by heating (Scheele and Burger 1980; Scheele and Weimers 1980; Burger and Scheele 1981; Scheele and Burger 1981). In the present experiments, the released $I_{2}$ tended to move throughout the system (it was not trapped by $\mathrm{PbX}$ ), and a portion of it was redistributed back onto the bottom of the $\mathrm{AgZ}$ bed.

A secondary problem involved severe corrosion of the stainless steel components, which occurred both during the drying stage and the subsequent stripping stage. During several of the cycles, the lines plugged with what appeared to be a mixture of $I_{2}$ and metal iodides. The most severe result of the corrosion, however, was the destruction of the stainless steel bellows in the circulating pump, pump no. 3, which was used in both the drying and stripping stages. The bellows in the pump would typically last for 3-6 runs. In a few of the runs, an additional charcoal or a zeolite trap was inserted in the line at point $b$ to remove iodine from the system.

It should be emphasized that the purpose of this work was to examine the behavior of $\mathrm{AgZ}$ under recycle. The remainder of the system was adjusted or modified occasionally to facilitate the operation and does not necessarily represent what would be used in an actual application.

Following the drying operation, hydrogen was passed into the system, replacing the argon, and the temperature of the $\mathrm{AgZ}$ bed raised to about $500^{\circ} \mathrm{C}$. This treatment removed the iodine, usually as HI. It was difficult to maintain a uniform temperature in the bed, and typically the very top of the bed was $30-50^{\circ}$ hotter than the remainder. A small bleed stream, about 100 $\mathrm{mL} / \mathrm{min}$ of $\mathrm{H}_{2}$, was continually added to the system. Before terminating the stripping stage, the circulating $\mathrm{H}_{2}$ was tested for $\mathrm{HI}$ by passing a portion through a fresh AgX bed.

The previous recycle work of Thomas and coworkers (1977, 1978), as well as more recent experiments in our laboratory, have shown that the reduced silver mordenite, $\mathrm{Ag}^{\circ} \mathrm{Z}$, is operable in the $\mathrm{NO}_{x}-\mathrm{H}_{2} \mathrm{O}$ concentration regimes 
typical of off-gas streams. Therefore, these variables, as well as temperature and flow rate, were fixed for this study. Details for each stage of the cycle are given in Tables 1 and 2.

TABLE 1: Zeolite ${ }^{(a)}$ Bed Descriptions

\begin{tabular}{lll} 
& \multicolumn{1}{c}{$\mathrm{AgZ}$} & $\underline{\mathrm{PbX}}$ \\
Bed diameter & $5 \mathrm{~cm}$ & $5 \mathrm{~cm}$ \\
Depth & $20 \mathrm{~cm}$ & $20 \mathrm{~cm}$ \\
Particle Size & $10-16$ mesh & $1.5 \mathrm{~mm}$ beads \\
Mass (dry) & $320 \mathrm{~g}$ & $400 \mathrm{~g}$ \\
Silver content & $0.55 \mathrm{~mol}$ & -- \\
Lead content & -- & $0.65 \mathrm{~mol}$
\end{tabular}

(a) Zeolites obtained from the Ionex Research Corporation, Broomfield, Colorado. The AgZ was $19 \% \mathrm{Ag}$ by weight (dry).

TABLE 2. Experimental Operating Conditions for AgZ and $\mathrm{PbX}$ Beds During Iodine Loading and AgZ Recycle

$-\frac{\text { Doading }}{\text { AgZ }} \quad \underline{\mathrm{PbX}} \quad \underline{\mathrm{AgZ}} \quad \underline{\mathrm{PbX}} \quad \underline{\mathrm{AgZ}} \underline{\mathrm{PbX}}$

\begin{tabular}{|c|c|c|c|c|c|c|}
\hline Temperature, ${ }^{\circ} \mathrm{C}$ & $150 \pm 10$ & $x$ & 300 & & $460-550$ & 150 \\
\hline Carrier gas & Air & $x$ & \multicolumn{2}{|c|}{$\begin{array}{c}\mathrm{Ar} \text { or } 6 \% \mathrm{H}_{2} \\
\text { in } \mathrm{He}\end{array}$} & \multicolumn{2}{|c|}{$\mathrm{H}_{2}$} \\
\hline Flow rate, L/min & 30 & $x$ & \multicolumn{2}{|c|}{$2-4$} & \multicolumn{2}{|c|}{$24-30$} \\
\hline $\mathrm{m} / \mathrm{min}$ & 15 & $x$ & \multicolumn{2}{|c|}{$1-2$} & \multicolumn{2}{|c|}{$12-15$} \\
\hline $\mathrm{I}_{2}$ conc, $\mu \mathrm{mol} / \mathrm{L}$ & $10-20$ & $x$ & \multicolumn{2}{|c|}{ Variable } & \multicolumn{2}{|c|}{ low. } \\
\hline $\mathrm{HI}$ conc, $\mu \mathrm{mol} / \mathrm{L}$ & 0 & $x$ & 0 & 0 & 0 & 20 (est.) \\
\hline $\mathrm{H}_{2} \mathrm{O}$ conc, $\mu \mathrm{mol} / \mathrm{L}$ & $200-500$ & $x$ & \multicolumn{2}{|c|}{ Variable } & \multicolumn{2}{|c|}{ Very low } \\
\hline${ }^{\mathrm{N}} \mathrm{x}_{\mathrm{x}}$ conc, $\%$ & 2 & $x$ & & 0 & 0 & 0 \\
\hline Run time, hr & $4-8$ & $x$ & $8-1$ & & \multicolumn{2}{|c|}{$12-24$} \\
\hline
\end{tabular}

$x-$ not in system 
$\underline{\text { RESULTS }}$

In this study, we used two separate beds. The first was loaded, stripped, and reloaded to test the system and check for reproducibility. The second was employed for the long-term recycle study.

The first loading was on unreduced $\mathrm{AgZ}$. The top of the bed loaded to about $160 \mathrm{mg} \mathrm{I} / \mathrm{g} \mathrm{AgZ}$, and the loading fell off rapidly below section 5 (the $12.5 \mathrm{~cm}$ mark as measured from the bed top). Stripping was completed in 20 hrs. The second loading on the reduced $\mathrm{Ag}^{\circ} \mathrm{Z}$ was higher - about $220 \mathrm{mg} \mathrm{I} / \mathrm{g} \mathrm{AgZ}$ at the top sections. Again, the concentrations fell off rapidly in sections 6, 7, and 8. Actual scan data are listed in Tables A.1-A.45 in the Appendix. The apparently low iodine concentration at the top of the bed in this and other runs is an artifact resulting from the counting geometry. The average iodine content for the first loading was $106 \mathrm{mg} \mathrm{I} / \mathrm{g} \mathrm{AgZ} \mathrm{zeolite,} \mathrm{and}$ for the second, $155 \mathrm{mg} \mathrm{I} / \mathrm{g} \mathrm{AgZ}$.

New AgZ was then placed in the reaction vessel and the second series of runs started. The first loading was similar to the first on bed 1 and produced a maximum concentration (loading) of about $160 \mathrm{mg} \mathrm{I/g} \mathrm{AgZ}$ and an average of $110 \mathrm{mg} \mathrm{I} / \mathrm{g} \mathrm{AgZ}$. The drying cycle for this run employed $6 \% \mathrm{H}_{2}$ in helium at $300^{\circ} \mathrm{C}$. About $21 \%$ of the iodine was removed during drying.

The $6 \% \mathrm{H}_{2}$-He test in place of argon was performed to eliminate residual $\mathrm{NO}_{\mathrm{X}}$ on the $\mathrm{AgZ}$ and to determine whether the elemental iodine released during the drying cycle could be converted to $\mathrm{HI}$ and trapped by the $\mathrm{PbX}$. Though apparently successful on both counts, we returned to the use of argon in subsequent runs since an inert gas was suggested for the recycle evaluation. We did, in later runs, employ the $6 \% \mathrm{H}_{2}$-He in an effort to reduce the corrosion problems attendant with the circulation of iodine.

After 5 cycles, a noticeable degradation of the bed became manifested in either or both a decreased loading capacity or more commonly a poor $I_{2}$ removal with the hydrogen stripping. At the end of the 10th run, following the normal stripping treatment, the total iodine remaining was still $137 \mathrm{mg} \mathrm{I} / \mathrm{g} \mathrm{AgZ}$. It was reloaded in run 11 and exposed to three separate hydrogen treatments for 23,21 , and $24 \mathrm{hrs}$, respectively, at about $530^{\circ} \mathrm{C}$, which finally reduced the

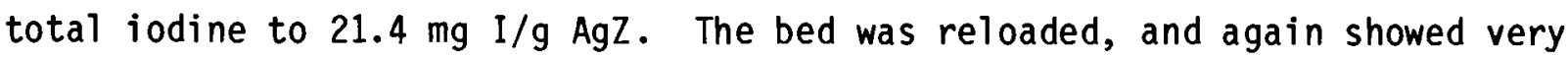
poor stripping behavior. The temperature was raised to $550-555^{\circ} \mathrm{C}$ and 
restripped. Most of the residual iodine (except that at the top of the bed) was removed. We concluded that the experimental apparatus was inadequate to furnish further information, and the work was terminated.

The runs beyond the initial loading are discussed individually below, and a brief summary is given in Table 3 .

Loading 2 averaged $120 \mathrm{mg} \mathrm{I} / \mathrm{g}$ AgZ with a maximum concentration of about 175. During drying, $18 \%$ was removed, and another $80 \%$ upon stripping with $\mathrm{H}_{2}$, leaving $2.4 \%$ of the $\mathrm{I}_{2}$ on the bed. A charcoal trap was $\mathrm{placed}$ in the loop in an attempt to trap some of the iodine volatilized as $\mathrm{I}_{2}$ during the drying stage and the first few minutes of the $\mathrm{H}_{2}$ stripping. It was largely ineffective; much of the $\mathrm{I}_{2}$ was deposited on tubing throughout the system.

Loading 3 averaged $104 \mathrm{mg} \mathrm{I/g} \mathrm{AgZ,} \mathrm{and} \mathrm{about} \mathrm{4 \%} \mathrm{was} \mathrm{removed} \mathrm{by} \mathrm{drying.} \mathrm{A}$ crack developed in the reaction vessel towards the end of the stripping. The

TABLE 3. Summary of Iodine Loading and Stripping

\begin{tabular}{|c|c|c|c|}
\hline Cycle & $\begin{array}{c}\text { Average } \\
\text { Cycle Loading } \\
\mathrm{mg} \mathrm{I/g} \mathrm{AgZ} \\
\end{array}$ & $\begin{array}{c}\text { Average } \\
\text { Total Loading } \\
\mathrm{mg} \mathrm{I/g} \mathrm{AgZ} \\
\end{array}$ & $\begin{array}{c}\text { Average } \\
\text { Total Loading } \\
\text { After Stripping } \\
\mathrm{mg} \mathrm{I} / \mathrm{g} \mathrm{AgZ} \\
\end{array}$ \\
\hline 1 & 110 & 110 & 0 \\
\hline 2 & 120 & 120 & 3 \\
\hline 3 & 101 & 104 & 11 \\
\hline 4 & 84 & 96 & 15 \\
\hline 5 & 69 & 84 & 60 \\
\hline 6 & 82 & 142 & 70 \\
\hline 7 & 125 & 195 & 114 \\
\hline 8 & 85 & 199 & 140 \\
\hline 9 & 61 & 201 & 123 \\
\hline 10 & 47 & 170 & 137 \\
\hline 11 & 58 & 195 & 21 \\
\hline 12 & 94 & 116 & 44 \\
\hline
\end{tabular}


zeolite was transferred in $2 \mathrm{~cm}$ segments to a new reaction vessel for completion of the cycle. About $92 \%$ of the remaining $\mathrm{I}_{2}$ was removed by hydrogen stripping at $500^{\circ} \mathrm{C}$, leaving about $2.7 \mathrm{~g} \mathrm{I}$ on the bed. The total iodine on the bed at this point was about $3.6 \mathrm{~g}$ I or $11.4 \mathrm{mg} \mathrm{I} / \mathrm{g} \mathrm{AgZ}$.

It may be noted that whether or not iodine is removed at the drying stage largely depends on the effectiveness of the trapping downstream from the AgZ bed. In a few cases, the removal was aided by leaks, which developed during the heat-up for drying! $I_{2}$ not removed from the circulating gas stream was deposited back on the $300^{\circ} \mathrm{C} \mathrm{AgZ}$ bed. In some cases, this was seen as an increased ${ }^{131_{I}}$ count at the bottom sections of the AgZ bed. $I_{2}$ was not trapped by the $\mathrm{PbX}$ bed. Even though hydrogen was present, a second release of $\mathrm{I}_{2}$ occurred when the $\mathrm{AgZ}$ bed was heated from 300 to $500^{\circ} \mathrm{C}$ for the stripping stage.

Loading 4 ran without complication and was completed in 4 hours to a maximum of about $145 \mathrm{mg} \mathrm{I} / \mathrm{g} \mathrm{AgZ}$ and an average of 96. In the drying step, all but about $2 \%$ of the released $\mathrm{I}_{2}$ was trapped back on the AgZ bed. About $95 \%$ of the cycle iodine was released by stripping with $\mathrm{H}_{2}$, leaving $4 \mathrm{mg} / \mathrm{g} \mathrm{AgZ}$ of the freshly deposited iodine for a total of about $15 \mathrm{mg} \mathrm{I} / \mathrm{g} \mathrm{AgZ}$ on the bed.

During cycle 5, a crack in the air preheater occurred and caused an interruption in the loading stage. Breakthrough occurred in a total of about 4 hours. During the drying stage, the bellows of the recirculating pump failed due to corrosion, and some iodine was lost from the system. Considerable iodine was also trapped in the condenser, Con-1. The maximum loading was

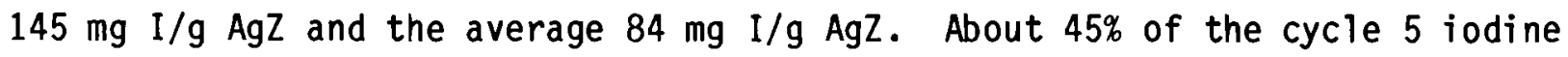
was removed during drying. During stripping, a new leak developed from corrosion through the $13 \mathrm{~mm}$ stainless tubing. After repair, a second hydrogenation step was carried out for a total stripping time of $54 \mathrm{hrs}$. Stripping removed $35 \%$ of the added iodine. At this point, considerable iodine remained on the bed. A total of about $60 \mathrm{mg} \mathrm{I} / \mathrm{g} \mathrm{AgZ}$ or $19 \mathrm{~g}$ I appeared to be rather firmly fixed in the zeolite.

Cycle 6 added about $26 \mathrm{~g}$ I during loading of about $82 \mathrm{mg} \mathrm{I/g} \mathrm{AgZ} \mathrm{(143} \mathrm{mg}$ $\mathrm{I} / \mathrm{g}$ AgZ total). The total iodine loading at the top of the bed was quite high at this point, over $200 \mathrm{mg} \mathrm{I} / \mathrm{g} \mathrm{AgZ}$. Drying removed 15\% of the cycle 6 iodine and somewhat leveled the distribution on the bed. Stripping removed an additional $79 \%$ and appeared to also remove a portion of the residual iodine from 
cycle 5 from bed sections 4 and 5 . The total iodine on the bed, at this time,

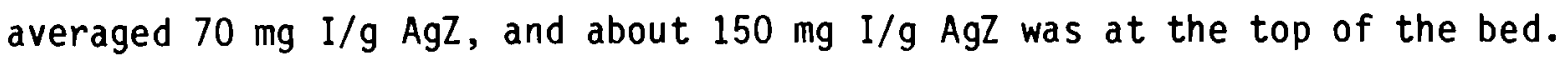

Cycle 7 was loaded over a 6 hour period, and an average of $195 \mathrm{mg} \mathrm{I} / \mathrm{g} \mathrm{AgZ}$ added to the bed before breakthrough. Note in Table A.21 that the loading at the top of the bed is very high, $336 \mathrm{mg} \mathrm{I/g} \mathrm{AgZ} \mathrm{(225} \mathrm{maximum} \mathrm{theoretical} \mathrm{on} \mathrm{a}$ total silver basis). The $5 \%$ of the $I_{2}$ removed by drying was deposited in the condensers and in the connecting tubing. Stripping for 28 hours, with temperatures ranging up to $540^{\circ} \mathrm{C}$, removed an additional $64 \%$. A second stripping at $500^{\circ} \mathrm{C}$ left the bed unchanged.

Cycle 8 loaded in about 2.5 hours. It was dried for 14 hours. A smal1 leak was repaired during the 27 hour stripping stage. Considerable reloading and redistribution of the iodine occurred during the drying stage. Actually, the ${ }^{131}$ I counting data suggest that some additional iodine may have been picked up from the remainder of the system and deposited on the AgZ. The uncertainty here is about $10 \%$ (see Appendix tables). Although nothing unusua 1 occurred during the run, the stripping stage removed much of the iodine from the top of the bed. This action had not been observed before. In spite of this 1oss, however, the residual iodine was still about $200 \mathrm{mg} \mathrm{I} / \mathrm{g} \mathrm{AgZ}$ at the top of the bed and averaged $140 \mathrm{mg} \mathrm{I} / \mathrm{g} \mathrm{AgZ}$ throughout the bed at the end of the cycle.

Cycle 9 took a nominal 3 hours to load. The loading reached a total iodine maximum of $290 \mathrm{mg} \mathrm{I} / \mathrm{g} \mathrm{AgZ} \mathrm{(82} \mathrm{mg} \mathrm{I} / \mathrm{g} \mathrm{AgZ} \mathrm{new} \mathrm{iodine)} \mathrm{and} \mathrm{a} \mathrm{total} \mathrm{iodine}$ average of $201 \mathrm{mg} \mathrm{I} / \mathrm{g} \mathrm{AgZ} \mathrm{(60} \mathrm{mg} \mathrm{I/g} \mathrm{AgZ} \mathrm{new} \mathrm{iodine).} \mathrm{Very} \mathrm{little} \mathrm{iodine} \mathrm{was}$ added to the bottom of the bed at breakthrough. Before drying, the circulating pump had to be repaired again, as the valves and bellows had been destroyed by corrosion. Drying removed $89 \%$ of the added iodine. The behavior on stripping was unusual. Iodine was removed from the central portions of the bed, including residual iodine from previous runs, and some was deposited at the top. However, the total iodine loading was not greatly reduced.

This loading was characterized by a pronounced pink color in the upper regions of the bed. Although various pink, red, and purple colors are common in iodine-loaded zeolites, the predominant color in these runs was yellow, with occasional dark orange patches or streaks. Typically, after a drying stage with argon, the bed was uniformly yellow. In contrast, cycle 1, which 
was dried with $6 \% \mathrm{H}_{2}$ in helium, was black. After $\mathrm{H}_{2}$ stripping, the bed was a light to medium gray color.

Although color is not necessarily indicative of iodine content -- it is probably associated with the $I_{2}$ interaction with oxygen sites in the zeolite lattices -- bands of color are informative. In these experiments, streaks of color often appeared vertically through the bed, suggesting some degree of channeling. We should mention that marked color changes in zeolites are not unique to iodine sorption. See for example, the paper of Jacobs and Uytterhoeven (1978).

Loading 10 required 2 hours to reach breakthrough. The loading added $15 \mathrm{~g} \mathrm{I}_{2}$, or an average of $47 \mathrm{mg} \mathrm{I} / \mathrm{g} \mathrm{AgZ,} \mathrm{giving} \mathrm{a} \mathrm{total} \mathrm{of} 170 \mathrm{mg} \mathrm{I} / \mathrm{g} \mathrm{AgZ}$. The peak total iodine loading again was high, $280 \mathrm{mg} \mathrm{I} / \mathrm{g} \mathrm{AgZ}$ at the top of the bed. The top quarter of the bed was pink, and a broad yellow streak extended through the remainder. Drying with the $6 \% \mathrm{H}_{2}$-He for 16 hours at $300-320^{\circ} \mathrm{C}$ removed $17 \%$ of the added iodine. After drying, the color varied from yellow at the bottom, through orange to pink, and to black at the top. A special charcoal trap placed downstream from the $\mathrm{PbX}$ bed picked up very little activity, but considerable iodine-containing liquid collected in the remainder of the system during both drying and stripping. Stripping with the usual $100 \% \mathrm{H}_{2}$ at $500-550^{\circ} \mathrm{C}$ for 20 hours only removed $53 \%$ more, leaving $14 \mathrm{mg} \mathrm{I} / \mathrm{g} \mathrm{AgZ}$ of the added iodine on the bed for a total of $137 \mathrm{mg} \mathrm{I} / \mathrm{g} \mathrm{AgZ}$.

Loading 11 required 2 hours and placed $18 \mathrm{~g}$ or $58 \mathrm{mg} \mathrm{I} / \mathrm{g} \mathrm{AgZ}$ on the bed. The bed was dried overnight with $6 \% \mathrm{H}_{2}$-He at $300^{\circ} \mathrm{C}$. Some of the iodine from the circulation loop was picked up and reloaded onto the AgZ bed. The

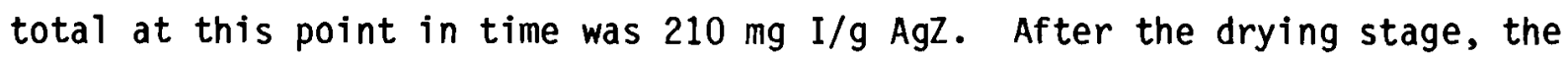
condensers and the charcoal trap were removed from the system and stripping carried out for 24 hours. During this strip, the temperature was low at the bottom of the bed, $\sim 425^{\circ}$. Considerable black, iodine-containing liquid again collected in the system. Insertion of the condensers into the system removed some of the liquid, but the tubing, valves, and rotometers had to be completely cleaned. The pump bellows had again corroded through, and the pump was replaced.

The system, after sitting idle and closed for 3 days, was dried again with $6 \% \mathrm{H}_{2}$-He, and the stripping continued for 23 hours at a uniform temperature throughout the bed of $520-540^{\circ} \mathrm{C}$. A third stripping of 18 hours 
was then employed at the same temperature. The bed was counted after each treatment.

The first 24 hour strip removed $93 \%$ of the iodine. This was the first really efficient stripping run since early in the tests. At the end of the third strip, the total iodine loading was down to $21 \mathrm{mg} \mathrm{I} / \mathrm{g} \mathrm{AgZ,} \mathrm{most} \mathrm{of} \mathrm{which}$ was at the bottom of the bed. The very bottom of the bed was a bright orange color at the end of the run.

Cycle 12 loaded normally, putting about $94 \mathrm{mg} \mathrm{I/g} \mathrm{AgZ} \mathrm{on} \mathrm{the} \mathrm{bed} \mathrm{with} \mathrm{a}$ maximum of $160 \mathrm{mg} \mathrm{I/g} \mathrm{AgZ.} \mathrm{The} \mathrm{total} \mathrm{iodine} \mathrm{was} 116 \mathrm{mg} \mathrm{I} / \mathrm{g} \mathrm{AgZ.} \mathrm{The} \mathrm{drying}$ stage was delayed due to pump failure (the bellows was again destroyed). Drying was finally accomplished by using argon from a cylinder and releasing it downstream from the $\mathrm{PbX}$ bed through a secondary AgX trap. A flow of 4 $\mathrm{L} / \mathrm{min}$ was used for about 20 hours. The drying temperature was slightly higher than normal, about $330^{\circ} \mathrm{C}$. This removed about $16 \%$ of the iodine, which was rather uniformly deposited at valves in the main line, in Con-1 and its receiver, and at the very top of the $\mathrm{PbX}$ bed.

For stripping, the temperature was maintained at $510^{\circ} \mathrm{C}$ or slightly below. No iodine was removed in 24 hours. An additional strip was tried, of 64 hours at the same temperature. About $47 \%$ of the iodine was stripped. A third stripping was added, of 48 hours, which removed a small amount. The net loading at the end of the final $500^{\circ} \mathrm{C}$ strip was $72 \mathrm{mg} \mathrm{I} / \mathrm{g} \mathrm{AgZ,} \mathrm{with} \mathrm{regions} \mathrm{at}$

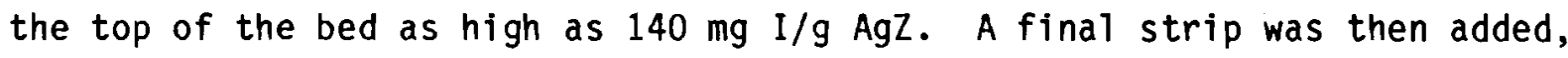
of $18 \mathrm{hrs}$ at a temperature of $550-555^{\circ} \mathrm{C}$. This removed $17 \%$ of the cycle 12 iodine, primarily from the upper part of the bed, leaving an average cycle iodine loading of $32 \mathrm{mg} \mathrm{I} / \mathrm{g} \mathrm{AgZ} \mathrm{(44} \mathrm{mg} \mathrm{I/g} \mathrm{AgZ} \mathrm{total).}$ 


\section{DISCUSSION}

Some comment on the nature of zeolites is necessary to appreciate the observations of this report. Mordenite is a high-silica zeolite of nominal composition $\mathrm{Na}_{2} \mathrm{O} \cdot \mathrm{Al}_{2} \mathrm{O}_{3} \cdot 10 \mathrm{SiO}_{2} \cdot 6 \mathrm{H}_{2} \mathrm{O}$. (a) Figure 2 presents a stereo view of its structure. There are two sets of channels. The main ones, $6.7 \times 7.0 \AA$, are linked in the same plane by small pockets having apertures of about $2.8 \AA$. Thus, only for small molecules is the channel system 2-dimensional. $I_{2}$ is $\sim 5.3 \AA$ along its longitudinal axis. Although blocking of the channels is common in natural mordenites as a result of impurities or crystal faults, this does not appear to be a problem with the synthetic material Zeolon ${ }^{\otimes}$ of the 8 sodium atoms of the unit cel1, 4 are in small cavities and 4 randomly situated in the large channels. All are apparently replaceable with silver ions; however, they are obviously not equally accessible.
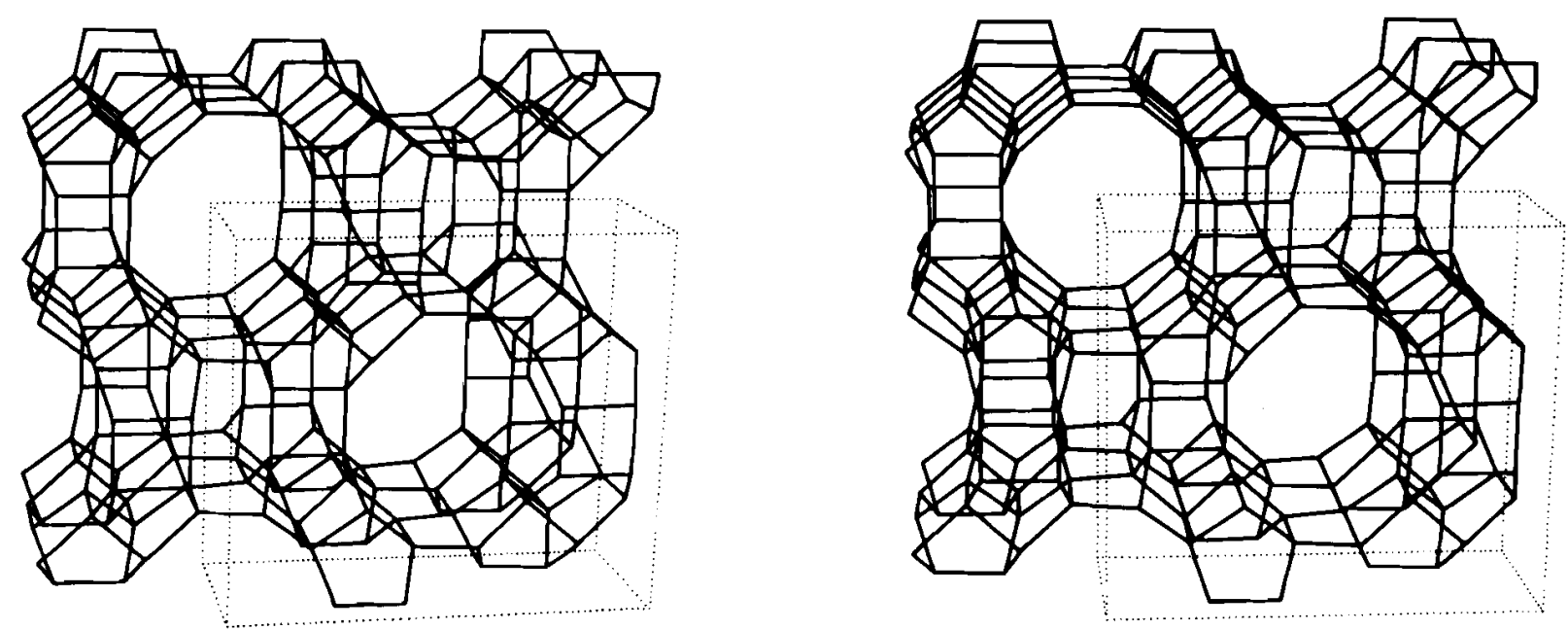

FIGURE 2. Stereo View of Sodium Mordenite, Reprinted with Permission from Meier and 01 son (1971). Copyright 1971 American Chemical Society.

(a) Breck (1974) gives a comprehensive survey of zeolite structures. ( Trademark of Norton Chemical Process Products Division, Akron, Ohio. 
$X$-ray structures of several cation-exchanged natural mordenites have been determined by Pluth and coworkers. See, for example, Schlenker, Pluth and Smith (1979). Powder patterns of several silver-substituted zeolites, including silver mordenite, were obtained by Vance and Agrawal (1982). However, no single crystal work has been reported, and the locations of the silver atoms are not certain. The information on mordenites is less well developed than for many other zeolites.

In this study, we have used Zeolon exclusively. The silver-exchanged material was prepared by Ionex Corporation and had a typical silver content of $19 \%$ (dry basis).

Three other comments are necessary. Random assemblies of water molecules in the zeolite cavities may act as micro solutions. Thus, solution phase reactions are possible, such as hydrolysis to form $\mathrm{Ag}_{2} \mathrm{O}$ and hydrogen mordenite.

The second comment concerns the reduction of the silver mordenite by hydrogen, which occurs in the stripping stage. The reduced silver atoms tend to form aggregates of considerable size, up to a micrometer in diameter. The extent of the migration of reduced-metal atoms in zeolites and the size of the aggregates or crystalites formed depend on the temperature and on the extent of hydration at the time of reduction. Low temperature and $10 \mathrm{w}$ water content favor the formation of smaller particles (Minachev and Isakov 1976). Figure 3 shows a 1000x magnification of a polished section of iodine-loaded $\mathrm{Ag}^{\circ} \mathrm{Z}$. Scanning electron microscopy, coupled with $x$-ray fluorescence, indicates that the white particles contain only silver and iodine. Similar scans of unloaded $\mathrm{Ag}^{\circ} \mathrm{Z}$ show silver metal particles which are the precursors of the AgI particles (Scheele et al. 1980).

Thirdly, stages of the recycle process, subsequent to the reduction, subject the silver particles to $\mathrm{H}_{2} \mathrm{O}+\mathrm{O}_{2}$ followed by $\mathrm{H}_{2} \mathrm{O}+\mathrm{NO}_{x}+\mathrm{I}_{2}$ and may redistribute some of the silver. However, the presence of $N 0$ is expected to keep the silver in reduced form during the loading stage (Thomas, Staples and Murphy 1978). Thus, silver aggregates are expected to be the normal occurrence, and they probably increase with each cycle. This has not been confirmed, however. The important point is that the chemistry of this loading, drying, stipping cycle is very complex and is probably not always 


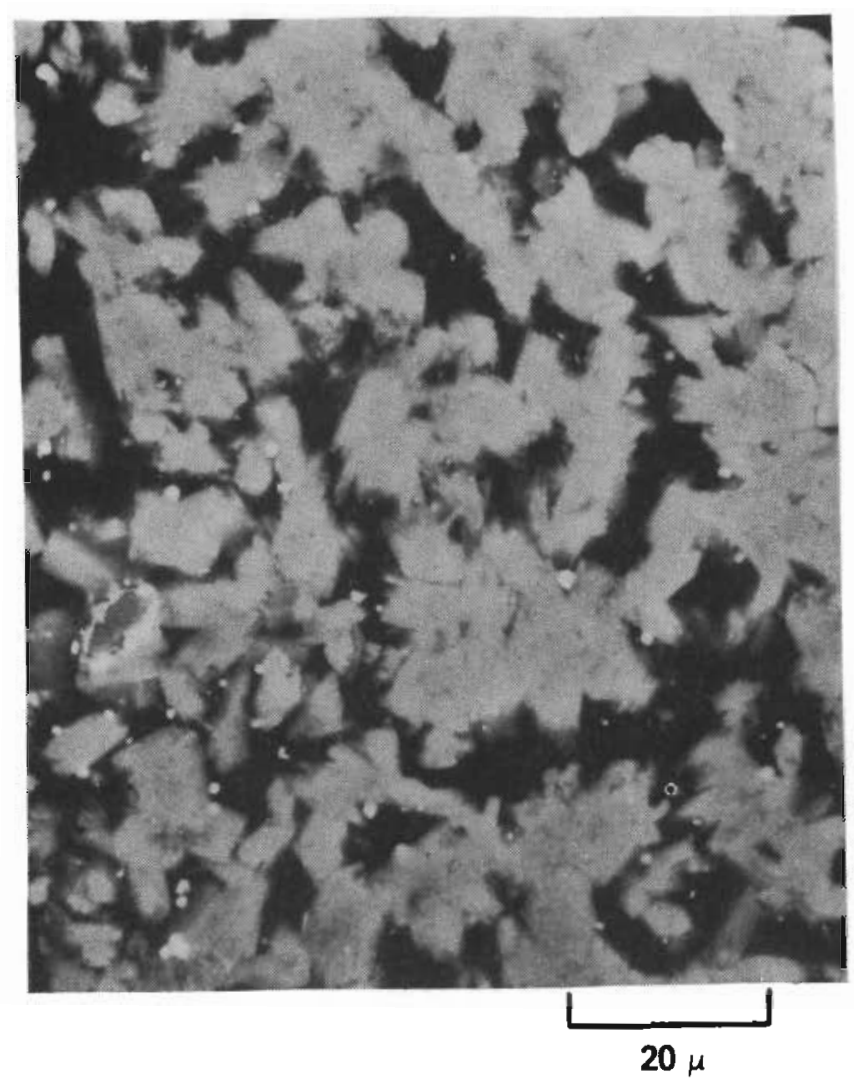

FIGURE 3. Scanning Electron Micrograph of $100 \mathrm{mg} \mathrm{I/g} \mathrm{Ag}{ }^{\circ} \mathrm{Z}$

reproducible under the conditions of the experiment. Unfortunately, the program did not permit us to examine the details of the chemical mechanisms.

The test result data confirm previous work that silver mordenite can indeed be recycled. There appears to be no major degradation of $\mathrm{Ag}^{\circ} \mathrm{Z}$ with respect to iodine pickup. However, there is evidence that stripping becomes more difficult as early as the 5th cycle. For the iodine held as AgI, the stripping is thermodynamically unfavorable, and the calculated HI partial pressures for the reaction $\mathrm{AgI}+1 / 2 \mathrm{H}_{2} \rightarrow \mathrm{Ag}^{\circ}+\mathrm{HI}$, based on data from Barin and Knacke (1973), are $9 \times 10^{-4} \mathrm{~atm}$ at $500^{\circ}$ and $3.2 \times 10^{-3} \mathrm{~atm}$ at $600^{\circ} \mathrm{C}$. The present experiments suggest that a temperature of $550^{\circ} \mathrm{C}$ or greater is desirable, in agreement with these calculations. However, it has been shown that AgZ loses its zeolitic structure at $700^{\circ} \mathrm{C}$ (Vance and Agrawal 1982). In the presence of $\mathrm{H}_{2} \mathrm{O}+\mathrm{NO}_{2}$, the maximum safe temperature may be even lower. It should also be noted that the volatility of silver iodide becomes appreciable above about $600^{\circ} \mathrm{C}$ (Scheele and Burger 1980). Thus, a fairly long reduction time at a lower temperature is probably necessary. 
Inspection of Tables A.1-A.45 indicates that the transfer zone is of the order of $10 \mathrm{~cm}$ under the conditions of the experiment. It would appear that a $15 \mathrm{~cm}$ bed could be loaded to a high capacity without breakthrough. Some channeling was observed with the 10-16 mesh material used here. Previous work at our laboratory has shown that the transfer zone is much shorter for 20-40 mesh zeolite and also at lower face velocities with 10-16 mesh Agz.

As was noted earlier, our previous work had shown that only about 25-30\% of the stoichiometric-loaded iodine on AgZ is chemically bound, e.g., as AgI and stable to heating. The remainder is molecularly bound and volatilizes as $I_{2}$, starting at about $250-300^{\circ} \mathrm{C}$. This has been confirmed by Vance and Agrawa 1 (1982). At the temperature of the reduction, $500-550^{\circ} \mathrm{C}$, much of the iodine is removed whether or not the hydrogen is present. A realistic recycle design would have to accommodate this fact rather than provide only for trapping HI.

Jubin (1980) had good success removing $\mathrm{I}_{2}$ from AgZ using $4.5 \% \mathrm{H}_{2}$ in argon. He found, however, that the zeolite was degraded with respect to further iodine loading.

Aside from the substitution of $6 \% \mathrm{H}_{2}$-He for argon in 3 runs, the drying stage was not studied. With virtually any flowing gas at $300^{\circ} \mathrm{C}$, zeolites can usually be dried in a few minutes to a small percentage of their saturated water content. The $\mathrm{NO}_{x}$ may add some complications. However, the overnight drying period was more of a convenience than a necessity. Although, as noted earlier, the amount of water in the zeolitic pores may influence the physical behavior of the silver during reduction, a separate drying cycle may actually be unnecessary.

Corrosion was severe during these experiments; the $\mathrm{HI}-\mathrm{I}_{2}-\mathrm{H}_{2} \mathrm{O}$ system is incompatible with stainless steel. Thus, Mone $1 \otimes$ or other construction materials need to be investigated.

In this study, we evaluated the effects of hydrogen recyle of $\mathrm{AgZ}$ on $\mathrm{I}_{2}$ capture and delayed study on the effect of AgZ recycle on organic iodide capture. However, other work has shown that hydrogen-reduced AgZ is an effective trap for methyl iodide (Scheele and Wiemers 1980; Scheele, Matsuzaki and Burger 1981). Recycled AgZ should behave similarly. 
In summary, AgZ can be recycled, but the cycle, as tested here, would have to be modified to trap $\mathrm{I}_{2}$-- a major release product -- before trapping the $\mathrm{HI}$ in $\mathrm{PbX}$. An alternative scheme might trap both in an aqueous system. It may be necessary to raise the stripping temperature to $550-600^{\circ} \mathrm{C}$. If it is, indeed, necessary to reuse the $\mathrm{AgZ}$, an alternative process would be: 1) to load AgZ to maximum capacity (this can be greater than theoretical), 2) to drive off the $60-80 \% \mathrm{I}_{2}$ not strongly bound with air or nitrogen at $400-600^{\circ} \mathrm{C}$, and 3) to reload with iodine. Series operation of beds should guarantee the required decontamination factor. Occasionally, if desired, a bed could be removed to a separate facility after the $400-600^{\circ} \mathrm{C}$ treatment and stripped with pure or dilute $\mathrm{H}_{2}$ at $550-600^{\circ} \mathrm{C}$. 
.

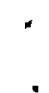




\section{ACKNOWLEDGEMENTS}

We would like to thank R. J. Elovich, C. L. Matsuzaki and L. A. Rogers for their help in the laboratory. We would also like to thank L. D. Maki and D. L. Futch for typing the report and S. F. Liebetrau for her editorial advice. 
. 
REFERENCES

Barin, I., and 0. Knacke. 1973. Thermochemical Properties of Inorganic Substances. Springer-Verlag, Berlin, Germany.

Breck, D. W. 1974. Zeolite Molecular Sieves. Wiley-Interscience, New York.

Burger, L. L. and R. D. Scheele. 1981. "Iodine Fixation Studies at the Pacific Northwest Laboratory." Paper Presented at the Specialists Meeting on Radioiodine Management, September 25, 1981, Brusse1s, Belgium.

PNL-SA-9829, Pacific Northwest Laboratory, Richland, Washington.

Burger, L. L., R. D. Scheele and K. D. Wiemers. 1981. Selection of a Form for Fixation of Iodine-129. PNL-4045, Pacific Northwest Laboratory, Richland, Washington.

Jacobs, P. A., J. B. Uytterhoeven and H. K. Beyer. 1978. "Some Unusual Properties of Activated and Reduced AgNaA Zeolites." J. Chem. Soc., Faraday Trans. I., 75: 56.

Jubin, R. T. 1980. Organic Iodine Removal from Simulated Dissolver Off-Gas Streams Using Silver-Exchanged Mordenite. Presented at the 16th DOE Air Cleaning Conference, San Diego, Catifornia.

Meier, W. T., and D. H. 01 son. 1971. "Zeolite Frameworks." In Molecular Sieve Zeolites, R. F. Gould, ed. Advances in Chemistry Series 101, ACS, Washington, D. C.

Minachev, K. H., and Y. I. Isakov. 1976. "Catalytic Properties of MetalContaining Zeolites." In Zeolite Chemistry and Catalysis, Ed. J. A. Rabo, pp. 552-611. ACS Monograph No. 171. American Chemical Society, Washington, D. C.

Murphy, L. P., B. A. Staples and T. R. Thomas. 1977. The Development of $\mathrm{Ag}^{\circ} \mathrm{Z}$ for Bulk ${ }^{129}$ I Removal from Nuclear Fuel Reprocessing Plants and PbX for I29I Storage. ICP-1135, Allied Chemical Corporation, Idaho Falls, Idaho.

Scheele, R. D., and L. L. Burger. 1981. "Characterization Studies of Iodine Loaded Silver Zeolites." PNL-SA-9510. Paper presented at the 182nd National Meeting of the American Chemical Society, August 23-28, 1981, New York.

Scheele, R. D., and L. L. Burger. 1980. "Iodine-129 Fixation," In Nuclear Waste Management Quarterly Progress Report, April Through June 1980. A. M. Platt and J. A. Powe 11, Eds. PNL-3000-6, Pacific Northwest Laboratory, Richland, Washington.

Scheele, R. D., C. L. Matsuzaki and L. L. Burger. 1981. "Iodine-129 Fixation." In Nuclear Waste Management Quarterly Progress Report October through December 1981, compiled by T. D. Chikalla and J. A. Powell. PNL-3000-10, Pacific Northwest Laboratory, Richland, Washington. 
Scheele, R. D., and K. D. Wiemers. 1980. "Iodine-129 Fixation." In Nuclear Waste Management Quarterly Progress Report, January Through March 1980. A. M. Platt and J. A. Powe 11, eds. PNL-3000-5, Pacific Northwest Laboratory, Richland, Washington.

Scheele, R. D., et a1. 1980. "Iodine-129 Fixation." In Nuclear Waste Management Quarterly Progress Report, July Through September 1980.

T. D. Chikalla and J. A. Powel1, eds. PNL-3000-7, Pacific Northwest Laboratory, Richland, Washington.

Schlenker, J. L., J. J. Pluth and J. V. Smith. 1979. "Positions of Cations and Molecules in Zeolites with the Mordenite-Type Framework $X$ Dehydrated Calcium Hydrogen Mordenite." Mat. Res. Bul1. 14(8):961-966.

Thomas, T. R., et al. 1977. Airborne Elemental Iodine Leading Capacities of Metal Zeolites and a Method for Recycling Silver Zeolite. ICP-1119, ATlied Chemicals Corporation, Idaho Falls, Idaho.

Thomas, T. R., B. A. Staples and L. P. Murphy. 1978. The Development of $\mathrm{Ag}^{\circ} \mathrm{Z}$ for Bulk ${ }^{129}$ I Removal from Nuclear Fuel Reprocessing Plants and PbX for 129 I Storage. Presented at the 15th D0E Nuclear Air CTeaning Conference, August 1978. Boston, Massachusetts. CONF 780819, p. 34.

Vance, E. R., and D. K. Agrawal. 1982. "X-ray Studies of Iodine Sorption in Some Silver Zeolites." J. Mat. Sci. 17: 1889-1894. 


\section{APPENDIX}

TABLES OF IODINE-LOADING CHARACTERISTICS FOR EACH CYCLE 
. 
TABLE A.1 Iodine-Loading Characteristics for AgZ Bed 1, Cycle 1, Loading Stage

\begin{tabular}{|c|c|c|}
\hline $\begin{array}{l}\text { Agz } \\
\text { Bed } \\
\text { Segment } \\
\end{array}$ & $\begin{array}{c}\text { Cycle } \\
\text { Loading, } \\
\text { g I }\end{array}$ & $\begin{array}{l}\text { Cycle } \\
\text { Loading, } \\
\text { mg I/g AgZ }\end{array}$ \\
\hline 1 & 6.0 & 148 \\
\hline 2 & 6.4 & 160 \\
\hline 3 & 6.2 & 154 \\
\hline 4 & 5.7 & 140 \\
\hline 5 & 4.8 & 118 \\
\hline 6 & 3.1 & 77 \\
\hline 7 & 1.4 & 34 \\
\hline 8 & 0.6 & 14 \\
\hline Total & 34.2 & \\
\hline Average & & 106 \\
\hline
\end{tabular}

TABLE A.2. Iodine-Loading Characteristics for AgZ Bed 1, Cycle 1, Drying Stage

\begin{tabular}{|c|c|c|}
\hline $\begin{array}{l}\text { AgZ } \\
\text { Bed } \\
\text { Segment } \\
\end{array}$ & $\begin{array}{c}\text { Cycle } \\
\text { Loading, } \\
\text { g I }\end{array}$ & $\begin{array}{l}\text { Cycle } \\
\text { Loading, } \\
\text { mg I/g AgZ }\end{array}$ \\
\hline 1 & 4.3 & 106 \\
\hline 2 & 4.7 & 116 \\
\hline 3 & 4.5 & 112 \\
\hline 4 & 4.3 & 106 \\
\hline 5 & 4.3 & 106 \\
\hline 6 & 4.3 & 107 \\
\hline 7 & 4.5 & 112 \\
\hline 8 & 3.3 & 82 \\
\hline Total & 34.2 & \\
\hline Average & & 106 \\
\hline
\end{tabular}


TABLE A.3. Iodine-Loading Characteristics for AgZ Bed 1, Cycle 2, Loading Stage

\begin{tabular}{|c|c|c|}
\hline $\begin{array}{l}\text { AgZ } \\
\text { Bed } \\
\text { Segment } \\
\end{array}$ & $\begin{array}{c}\text { Cycle } \\
\text { Loading, } \\
\text { g I } \\
\end{array}$ & $\begin{array}{l}\text { Cycle } \\
\text { Loading, } \\
\mathrm{mg} \mathrm{I} / \mathrm{g} \text { AgZ }\end{array}$ \\
\hline 1 & 6.3 & 157 \\
\hline 2 & 8.4 & 202 \\
\hline 3 & 8.8 & 217 \\
\hline 4 & 7.9 & 196 \\
\hline 5 & 8.7 & 216 \\
\hline 6 & 4.8 & 118 \\
\hline 7 & 2.5 & 63 \\
\hline 8 & 2.2 & 54 \\
\hline Total & 49.7 & \\
\hline Average & & 155 \\
\hline
\end{tabular}

A.2 
TABLE A.4. Iodine-Loading Characteristics for AgZ Bed 2, Cycle 1, Loading Stage

\begin{tabular}{|c|c|c|}
\hline $\begin{array}{l}\mathrm{AgZ} \\
\text { Bed } \\
\text { Segment } \\
\end{array}$ & $\begin{array}{c}\text { Cycle } \\
\text { Loading, } \\
\text { g I }\end{array}$ & $\begin{array}{c}\text { Cycle } \\
\text { Loading, } \\
\mathrm{mg} \mathrm{I/g} \mathrm{AgZ} \\
\end{array}$ \\
\hline 1 & 5.8 & 136 \\
\hline 2 & 6.5 & 152 \\
\hline 3 & 6.3 & 147 \\
\hline 4 & 6.0 & 142 \\
\hline 5 & 5.4 & 126 \\
\hline 6 & 4.2 & 99 \\
\hline 7 & 2.6 & 61 \\
\hline 8 & 0.7 & 17 \\
\hline Total & 37.6 & \\
\hline Average & & 110 \\
\hline$\underline{\text { TABLE A.5. }}$ & \multicolumn{2}{|c|}{$\begin{array}{l}\text { Iodine-Loading Characteristics for } \\
\text { AgZ Bed 2, Cycle 1, Drying Stage }\end{array}$} \\
\hline $\begin{array}{c}\text { Agz } \\
\text { Bed } \\
\text { Segment } \\
\end{array}$ & $\begin{array}{c}\text { Cycle } \\
\text { Loading, } \\
\text { g I }\end{array}$ & $\begin{array}{l}\text { Cycle } \\
\text { Loading, } \\
\text { mg I/g AgZ }\end{array}$ \\
\hline 1 & 5.1 & 118 \\
\hline 2 & 5.2 & 122 \\
\hline 3 & 5.1 & 120 \\
\hline 4 & 4.7 & 110 \\
\hline 5 & 4.2 & 99 \\
\hline 6 & 3.2 & 76 \\
\hline 7 & 1.8 & 43 \\
\hline 8 & 0.33 & 8 \\
\hline Total & 29.8 & \\
\hline Average & & 87 \\
\hline
\end{tabular}

$79.2 \%$ of cycle iodine remains. 
TABLE A.6. Iodine-Loading Characteristics for AgZ Bed 2, Cycle 2, Loading Stage

\section{AgZ \\ Bed \\ Segment}

1

2

3

4

5

6

7

8

Tota1

Average

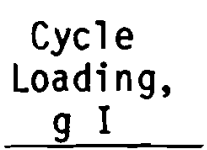

6.3

7.0

6.8

6.4

5.2

4.0

2.2

0.71

38.5
Cycle Loading, $\mathrm{mg} \mathrm{I} / \mathrm{g} \mathrm{AgZ}$

157

175

169

160

131

100

55

18

TABLE A.7. Iodine-Loading Characteristics for AgZ Bed 2, Cycle 2, Drying Stage

Agz
Bed
Segm

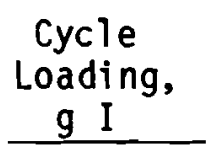

5.4

5.9

5.4

4.8

4.1

3.3

1.8

0.61

31.4
Total

Average

Cycle Loading, $\mathrm{mg} \mathrm{I/g} \mathrm{AgZ}$

136

148

136

119

102

83

46

15

$81.5 \%$ of cycle iodine remains. 
TABLE A.8. Iodine-Loading Characteristics for Agz Bed 2, Cycle 2, Stripping Stage

\begin{tabular}{|c|c|c|}
\hline $\begin{array}{l}\text { AgZ } \\
\text { Bed } \\
\text { Segment } \\
\end{array}$ & $\begin{array}{c}\text { Cycle } \\
\text { Loading, } \\
\text { g I } \\
\end{array}$ & $\begin{array}{l}\text { Cycle } \\
\text { Loading, } \\
\mathrm{mg} \mathrm{I/g} \mathrm{AgZ}\end{array}$ \\
\hline 1 & 0.05 & 1.3 \\
\hline 2 & 0.01 & 0.3 \\
\hline 3 & 0.08 & 2.0 \\
\hline 4 & 0.10 & 2.5 \\
\hline 5 & 0.10 & 2.5 \\
\hline 6 & 0.08 & 1.9 \\
\hline 7 & 0.18 & 4.4 \\
\hline 8 & 0.35 & 8.6 \\
\hline Total & 0.94 & \\
\hline Average & & 2.9 \\
\hline
\end{tabular}


TABLE A.9. Iodine-Loading Characteristics for AgZ Bed 2, Cycle 3, Loading Stage

\begin{tabular}{ccccc}
$\begin{array}{c}\text { AgZ } \\
\text { Bed } \\
\text { Segment }\end{array}$ & $\begin{array}{c}\text { Cycle } \\
\text { Loading, } \\
\text { g I }\end{array}$ & $\begin{array}{c}\text { Cycle } \\
\text { Loading, } \\
\text { mg I/g AgZ }\end{array}$ & & $\begin{array}{c}\text { Total } \\
\text { Loading } \\
\text { mg I/g AgZ }\end{array}$ \\
\cline { 5 - 5 } 2 & 6.1 & & 152 & 153 \\
3 & 7.0 & & 175 & 175 \\
4 & 6.8 & 169 & 171 \\
5 & 5.9 & 148 & 150 \\
6 & 4.0 & 101 & 104 \\
7 & 1.8 & & 45 & 47 \\
8 & 0.6 & 15 & 20
\end{tabular}

Total $\quad 32.2$

Average

101

104

TABLE A.10. Iodine-Loading Characteristics for AgZ Bed 2, Cycle 3, Drying Stage

\begin{tabular}{|c|c|c|c|}
\hline $\begin{array}{l}\text { AgZ } \\
\text { Bed } \\
\text { Segment }\end{array}$ & $\begin{array}{l}\text { Cycle } \\
\text { Loading, } \\
\text { g I }\end{array}$ & $\begin{array}{l}\text { Cycle } \\
\text { Loading, } \\
\mathrm{mg} \mathrm{I/g} \mathrm{AgZ}\end{array}$ & $\begin{array}{l}\text { Total } \\
\text { Loading } \\
\mathrm{mg} \mathrm{I} / \mathrm{g} \text { AgZ }\end{array}$ \\
\hline
\end{tabular}

$\begin{array}{rrrr}1 & 6.9 & 172 & 174 \\ 2 & 6.4 & 160 & 160 \\ 3 & 6.0 & 150 & 152 \\ 4 & 5.1 & 128 & 130 \\ 5 & 3.6 & 90 & 92 \\ 6 & 1.9 & 48 & 51 \\ 7 & 0.73 & 18 & 23 \\ 8 & 0.20 & 5 & 14\end{array}$

Total $\quad 30.8$

$\begin{array}{lll}\text { Average } & 96 & 99\end{array}$

$95.7 \%$ of cycle iodine remains. 
TABLE A.11. Iodine-Loading Characteristics for AgZ Bed 2, Cycle 3, Stripping Stage

\begin{tabular}{|c|c|c|c|}
\hline $\begin{array}{l}\text { AgZ } \\
\text { Bed } \\
\text { Segment } \\
\end{array}$ & $\begin{array}{c}\text { Cycle } \\
\text { Loading, } \\
\text { g I } \\
\end{array}$ & $\begin{array}{c}\text { Cycle } \\
\text { Loading, } \\
\text { mg I/g AgZ }\end{array}$ & $\begin{array}{l}\text { Total } \\
\text { Loading, } \\
\text { mg I/g AgZ }\end{array}$ \\
\hline 1 & 0.39 & 10 & 11 \\
\hline 2 & 0.34 & 8 & 9 \\
\hline 3 & 0.29 & 7 & 9 \\
\hline 4 & 0.40 & 9 & 12 \\
\hline 5 & 0.34 & 8 & 11 \\
\hline 6 & 0.36 & 9 & 11 \\
\hline 7 & 0.08 & 2 & 6 \\
\hline 8 & 0.52 & 13 & 22 \\
\hline Total & 2.71 & & \\
\hline Average & & 8 & 11 \\
\hline
\end{tabular}

8.4\% of cycle iodine remains. 
TABLE A.12. Iodine-Loading Characteristics for Agz Bed 2, Cycle 4, Loading Stage

\begin{tabular}{|c|c|c|c|}
\hline $\begin{array}{l}\text { AgZ } \\
\text { Bed } \\
\text { Segment } \\
\end{array}$ & $\begin{array}{c}\text { Cycle } \\
\text { Loading, } \\
\text { g I } \\
\end{array}$ & $\begin{array}{l}\text { Cycle } \\
\text { Loading, } \\
\text { mg I/g AgZ } \\
\end{array}$ & $\begin{array}{l}\text { Total } \\
\text { Loading, } \\
\text { mg I/g AgZ } \\
\end{array}$ \\
\hline 1 & 4.7 & 116 & 128 \\
\hline 2 & 5.4 & 136 & 145 \\
\hline 3 & 4.8 & 119 & 128 \\
\hline 4 & 4.3 & 107 & 119 \\
\hline 5 & 3.6 & 91 & 102 \\
\hline 6 & 2.4 & 61 & 72 \\
\hline 7 & 1.4 & 34 & 40 \\
\hline 8 & 0.44 & 11 & 22 \\
\hline Total & 27.0 & & \\
\hline Average & & 84 & 96 \\
\hline
\end{tabular}

TABLE A.13. Iodine-Loading Characteristics for AgZ Bed 2, Cycle 4, Drying Stage

\begin{tabular}{ccccc}
$\begin{array}{c}\text { AgZ } \\
\text { Bed } \\
\text { Segment }\end{array}$ & $\begin{array}{c}\text { Cycle } \\
\text { Loading, } \\
\text { g I }\end{array}$ & $\begin{array}{c}\text { Cycle } \\
\text { Loading, } \\
\text { mg I/g AgZ }\end{array}$ & $\begin{array}{c}\text { Total } \\
\text { Loading, } \\
\text { mg I/g AgZ }\end{array}$ \\
\cline { 5 - 5 } 1 & 3.8 & 96 & 97 \\
2 & 5.0 & 125 & 134 \\
3 & 4.6 & 115 & 124 \\
4 & 4.3 & 106 & 118 \\
5 & 3.8 & 95 & 106 \\
6 & 2.7 & 68 & 79 \\
7 & 1.5 & 38 & 44 \\
8 & 0.46 & 12 & 32 \\
Total & 26.4 & & \\
Average & & & &
\end{tabular}

$97.8 \%$ of cycle iodine remains. 
TABLE A.14. Iodine-Loading Characteristics for

AgZ Bed 2, Cycle 4, Stripping Stage

\begin{tabular}{|c|c|c|c|}
\hline $\begin{array}{l}\text { AgZ } \\
\text { Bed } \\
\text { Segment } \\
\end{array}$ & $\begin{array}{c}\text { Cycle } \\
\text { Loading, } \\
\text { g I } \\
\end{array}$ & $\begin{array}{l}\text { Cycle } \\
\text { Loading, } \\
\text { mg I/g AgZ }\end{array}$ & $\begin{array}{l}\text { Total } \\
\text { Loading, } \\
\mathrm{mg} \mathrm{I/g} \mathrm{AgZ}\end{array}$ \\
\hline
\end{tabular}

$\begin{array}{llll}1 & 0.07 & 2 & 13 \\ 2 & 0.05 & 1 & 10 \\ 3 & 0.11 & 3 & 12 \\ 4 & 0.11 & 3 & 15 \\ 5 & 0.16 & 4 & 15 \\ 6 & 0.17 & 4 & 15 \\ 7 & 0.23 & 6 & 12 \\ 8 & 0.33 & 8 & 30\end{array}$

Total $\quad 1.23$

Average 15

$4.7 \%$ of cycle iodine remains. 
TABLE A.15. Iodine-Loading Characteristics for

AgZ Bed 2, Cycle 5, Loading Stage

\begin{tabular}{ccccc}
$\begin{array}{c}\text { Agz } \\
\text { Bed } \\
\text { Segment }\end{array}$ & $\begin{array}{c}\text { Cycle } \\
\text { Loading, } \\
\text { g I }\end{array}$ & $\begin{array}{c}\text { Cycle } \\
\text { Loading, } \\
\text { mg I/g AgZ }\end{array}$ & $\begin{array}{c}\text { Total } \\
\text { Loading, } \\
\text { mg I/g AgZ }\end{array}$ \\
\cline { 1 - 2 } 1 & 2.9 & 72 & 84 \\
2 & 5.3 & 133 & 143 \\
3 & 5.0 & 124 & 136 \\
4 & 3.9 & 97 & 112 \\
5 & 2.2 & 56 & 71 \\
6 & 1.2 & 29 & 44 \\
7 & 0.65 & 16 & 28 \\
8 & 0.25 & 6 & 36
\end{tabular}

Total 22.0

Average

69

84

TABLE A.16. Iodine-Loading Characteristics for AgZ Bed 2, Cycle 5, Drying Stage

\begin{tabular}{|c|c|c|c|}
\hline $\begin{array}{l}\text { AgZ } \\
\text { Bed } \\
\text { Segment } \\
\end{array}$ & $\begin{array}{l}\text { Cycle } \\
\text { Loading, } \\
\text { g I } \\
\end{array}$ & $\begin{array}{l}\text { Cycle } \\
\text { Loading, } \\
\text { mg I/g AgZ }\end{array}$ & $\begin{array}{l}\text { Total } \\
\text { Loading } \\
\mathrm{mg} \mathrm{I/g} \mathrm{AgZ}\end{array}$ \\
\hline 1 & 0.93 & 23 & 36 \\
\hline 2 & 3.1 & 78 & 87 \\
\hline 3 & 3.1 & 78 & 90 \\
\hline 4 & 2.6 & 65 & 80 \\
\hline 5 & 1.6 & 39 & 54 \\
\hline 6 & 0.61 & 15 & 30 \\
\hline 7 & 0.18 & 4 & 17 \\
\hline 8 & 0.07 & 2 & 32 \\
\hline Total & 12.2 & & \\
\hline Average & & 38 & 53 \\
\hline
\end{tabular}

$55.1 \%$ of cycle loading remains. 
TABLE A.17. Iodine-Loading Characteristics for Agz Bed 2, Cycle 5, Stripping Stage

\begin{tabular}{|c|c|c|c|}
\hline $\begin{array}{l}\text { AgZ } \\
\text { Bed } \\
\text { Segment } \\
\end{array}$ & $\begin{array}{c}\text { Cycle } \\
\text { Loading, } \\
\text { g I } \\
\end{array}$ & $\begin{array}{l}\text { Cycle } \\
\text { Loading, } \\
\mathrm{mg} \mathrm{I/g} \mathrm{Agz}\end{array}$ & $\begin{array}{l}\text { Total } \\
\text { Loading, } \\
\text { mg I/g AgZ }\end{array}$ \\
\hline 1 & 2.5 & 63 & 76 \\
\hline 2 & 3.6 & 90 & 100 \\
\hline 3 & 3.6 & 89 & 101 \\
\hline 4 & 2.3 & 57 & 72 \\
\hline 5 & 0.66 & 16 & 31 \\
\hline 6 & 0.15 & 4 & 19 \\
\hline 7 & 0.14 & 4 & 16 \\
\hline 8 & 0.56 & 14 & 44 \\
\hline Total & 14.2 & & \\
\hline Average & & 44 & 60 \\
\hline
\end{tabular}

$64.5 \%$ of cycle iodine remains. 
TABLE A.18. Iodine-Loading Characteristics for Agz Bed 2, Cycle 6, Loading Stage

\begin{tabular}{|c|c|c|c|}
\hline $\begin{array}{l}\text { Agz } \\
\text { Bed } \\
\text { Segment } \\
\end{array}$ & $\begin{array}{c}\text { Cycle } \\
\text { Loading, } \\
\text { g I } \\
\end{array}$ & $\begin{array}{l}\text { Cycle } \\
\text { Loading, } \\
\mathrm{mg} \mathrm{I/g} \mathrm{AgZ} \\
\end{array}$ & $\begin{array}{l}\text { Total } \\
\text { Loading, } \\
\mathrm{mg} \mathrm{I} / \mathrm{g} \mathrm{AgZ} \\
\end{array}$ \\
\hline 1 & 3.2 & 79 & 155 \\
\hline 2 & 4.4 & 111 & 211 \\
\hline 3 & 4.7 & 117 & 218 \\
\hline 4 & 4.8 & 120 & 192 \\
\hline 5 & 4.4 & 111 & 142 \\
\hline 6 & 2.5 & 63 & 82 \\
\hline 7 & 1.6 & 40 & 56 \\
\hline 8 & 0.69 & 17 & 61 \\
\hline
\end{tabular}

Total 26.4

$\begin{array}{lll}\text { Average } & 82 & 142\end{array}$

TABLE A.19. Iodine-Loading Characteristics for AgZ Bed 2, Cycle 6, Drying Stage

\begin{tabular}{|c|c|c|c|}
\hline $\begin{array}{l}\text { AgZ } \\
\text { Bed } \\
\text { Segment }\end{array}$ & $\begin{array}{c}\text { Cycle } \\
\text { Loading, } \\
\text { g I } \\
\end{array}$ & $\begin{array}{l}\text { Cycle } \\
\text { Loading, } \\
\mathrm{mg} \mathrm{I} / \mathrm{g} \text { AgZ }\end{array}$ & $\begin{array}{l}\text { Total } \\
\text { Loading, } \\
\text { mg I/g AgZ }\end{array}$ \\
\hline 1 & 1.8 & 45 & 121 \\
\hline 2 & 2.7 & 66 & 166 \\
\hline 3 & 2.6 & 64 & 165 \\
\hline 4 & 7.7 & 192 & 264 \\
\hline 5 & 3.6 & 90 & 121 \\
\hline 6 & 2.1 & 54 & 72 \\
\hline 7 & 1.4 & 35 & 50 \\
\hline 8 & 0.45 & 11 & 55 \\
\hline Tota1 & 22.3 & & \\
\hline Average & & 70 & 129 \\
\hline
\end{tabular}

$84.5 \%$ of cycle iodine remains. 
TABLE A.20. Iodine-Loading Characteristics for AgZ Bed 2, Cycle 6, Stripping Stage

\begin{tabular}{|c|c|c|c|}
\hline $\begin{array}{c}\text { Agz } \\
\text { Bed } \\
\text { Segment } \\
\end{array}$ & $\begin{array}{c}\text { Cycle } \\
\text { Loading, } \\
\text { g I } \\
\end{array}$ & $\begin{array}{l}\text { Cycle } \\
\text { Loading, } \\
\text { mg I/g AgZ }\end{array}$ & $\begin{array}{l}\text { Total } \\
\text { Loading, } \\
\text { mg I/g AgZ }\end{array}$ \\
\hline 1 & 2.7 & 66 & 142 \\
\hline 2 & 2.3 & 58 & 158 \\
\hline 3 & 0.22 & 5 & 106 \\
\hline 4 & 0 & 0 & 34 \\
\hline 5 & 0 & 0 & 31 \\
\hline 6 & 0.13 & 3 & 22 \\
\hline 7 & 0.04 & 1 & 17 \\
\hline 8 & 0.10 & 2 & 46 \\
\hline Total & 5.49 & & \\
\hline Average & & 17 & 70 \\
\hline
\end{tabular}

$20.7 \%$ of cycle iodine remains. 
TABLE A.21. Iodine-Loading Characteristics for AgZ Bed 2, Cycle 7, Loading Stage

\begin{tabular}{ccccc}
$\begin{array}{c}\text { Agz } \\
\text { Bed } \\
\text { Segment }\end{array}$ & $\begin{array}{c}\text { Cycle } \\
\text { Loading, } \\
\text { g I }\end{array}$ & & $\begin{array}{c}\text { Cycle } \\
\text { Loading, } \\
\text { mg I/g AgZ }\end{array}$ & $\begin{array}{c}\text { Total } \\
\text { Loading, } \\
\text { mg I/g AgZ }\end{array}$ \\
\cline { 5 - 5 } 1 & 4.5 & & 113 & \\
\cline { 5 - 5 } 2 & 7.1 & 178 & 255 \\
3 & 8.3 & 207 & 336 \\
4 & 8.1 & 202 & 313 \\
5 & 5.8 & 144 & 236 \\
6 & 3.2 & 80 & 175 \\
7 & 2.2 & 54 & 702 \\
8 & 0.98 & 24 & 71
\end{tabular}

$\begin{array}{lrrr}\text { Total } & 40.0 & & \\ \text { Average } & & 125 & 195\end{array}$

TABLE A.22. Iodine-Loading Characteristics for AgZ Bed 2, Cycle 7, Drying Stage

\begin{tabular}{|c|c|c|c|}
\hline $\begin{array}{l}\text { Agz } \\
\text { Bed } \\
\text { Segment } \\
\end{array}$ & $\begin{array}{c}\text { Cycle } \\
\text { Loading, } \\
\text { g I } \\
\end{array}$ & $\begin{array}{l}\text { Cycle } \\
\text { Loading, } \\
\mathrm{mg} \mathrm{I/g} \mathrm{Agz}\end{array}$ & $\begin{array}{l}\text { Total } \\
\text { Loading, } \\
\text { m } \mathrm{gI} / \mathrm{g} \text { AgZ }\end{array}$ \\
\hline 1 & 4.3 & 107 & 249 \\
\hline 2 & 6.1 & 151 & 309 \\
\hline 3 & 7.3 & 182 & 288 \\
\hline 4 & 7.0 & 175 & 209 \\
\hline 5 & 6.4 & 159 & 190 \\
\hline 6 & 3.7 & 93 & 115 \\
\hline 7 & 2.3 & 57 & 74 \\
\hline 8 & 1.0 & 25 & 71 \\
\hline Total & 38.0 & & \\
\hline Average & & 119 & 189 \\
\hline
\end{tabular}

$95.0 \%$ of cycle iodine remains. 
TABLE A.23. Iodine-Loading Characteristics for AgZ Bed 2, Cycle 7, Stripping Stage \#1

\begin{tabular}{|c|c|c|c|}
\hline $\begin{array}{l}\text { Agz } \\
\text { Bed } \\
\text { Segment } \\
\end{array}$ & $\begin{array}{c}\text { Cycle } \\
\text { Loading, } \\
\text { g I } \\
\end{array}$ & $\begin{array}{l}\text { Cycle } \\
\text { Loading, } \\
\text { mg I/g AgZ }\end{array}$ & $\begin{array}{l}\text { Total } \\
\text { Loading } \\
\text { mg I/g AgZ } \\
\end{array}$ \\
\hline 1 & 1.4 & 36 & 178 \\
\hline 2 & 2.0 & 50 & 208 \\
\hline 3 & 3.0 & 74 & 180 \\
\hline 4 & 3.0 & 75 & 110 \\
\hline 5 & 2.4 & 61 & 93 \\
\hline 6 & 1.1 & 26 & 48 \\
\hline 7 & 0.71 & 18 & 34 \\
\hline 8 & 0.63 & 16 & 62 \\
\hline
\end{tabular}

Total $\quad 14.3$

Average 45

114

$35.7 \%$ of cycle iodine remains.

TABLE A.24. Iodine-Loading Characteristics for AgZ Bed 2, Cycle 7, Stripping Stage \#2

\begin{tabular}{cccc}
$\begin{array}{c}\text { AgZ } \\
\text { Bed }\end{array}$ & $\begin{array}{c}\text { Cycle } \\
\text { Loading, } \\
\text { Segment }\end{array}$ & $\begin{array}{c}\text { Cycle } \\
\text { Loading, }\end{array}$ & $\begin{array}{c}\text { Total } \\
\text { Loading }\end{array}$ \\
\hline
\end{tabular}

$\begin{array}{llll}1 & 1.8 & 45 & 187 \\ 2 & 2.1 & 53 & 211 \\ 3 & 2.9 & 72 & 178 \\ 4 & 2.9 & 72 & 106 \\ 5 & 2.3 & 57 & 88 \\ 6 & 0.88 & 22 & 44 \\ 7 & 0.65 & 16 & 33 \\ 8 & 0.76 & 19 & 15\end{array}$

Total

14.3

Average

$37.9 \%$ of cycle iodine remains. 
TABLE A.25. Iodine-Loading Characteristics for AgZ Bed 2, Cycle 8, Loading Stage

\begin{tabular}{|c|c|c|c|}
\hline $\begin{array}{l}\text { AgZ } \\
\text { Bed } \\
\text { Segment } \\
\end{array}$ & $\begin{array}{c}\text { Cycle } \\
\text { Loading, } \\
\text { g I }\end{array}$ & $\begin{array}{l}\text { Cycle } \\
\text { Loading, } \\
\text { mg I/g AgZ }\end{array}$ & $\begin{array}{l}\text { Total } \\
\text { Loading } \\
\text { mg I/g AgZ }\end{array}$ \\
\hline 1 & 3.8 & 95 & 282 \\
\hline 2 & 5.3 & 132 & 343 \\
\hline 3 & 4.6 & 114 & 292 \\
\hline 4 & 3.9 & 97 & 203 \\
\hline 5 & 3.3 & 83 & 172 \\
\hline 6 & 2.8 & 70 & 114 \\
\hline 7 & 2.4 & 61 & 94 \\
\hline 8 & 0.99 & 25 & 90 \\
\hline Total & 27.1 & & \\
\hline Average & & 85 & 199 \\
\hline
\end{tabular}

TABLE A.26. Iodine-Loading Characteristics for AgZ Bed 2, Cycle 8, Drying Stage

\begin{tabular}{|c|c|c|c|}
\hline $\begin{array}{l}\text { Agz } \\
\text { Bed } \\
\text { Segment } \\
\end{array}$ & $\begin{array}{c}\text { Cycle } \\
\text { Loading, } \\
\text { g I } \\
\end{array}$ & $\begin{array}{l}\text { Cycle } \\
\text { Loading, } \\
\mathrm{mg} \mathrm{I/g} \mathrm{AgZ} \\
\end{array}$ & $\begin{array}{l}\text { Total } \\
\text { Loading } \\
\mathrm{mg} \mathrm{I/g} \mathrm{AgZ} \\
\end{array}$ \\
\hline 1 & 2.7 & 68 & 265 \\
\hline 2 & 3.8 & 95 & 320 \\
\hline 3 & 3.8 & 94 & 286 \\
\hline 4 & 3.6 & 89 & 208 \\
\hline 5 & 3.9 & 97 & 200 \\
\hline 6 & 4.3 & 107 & 167 \\
\hline 7 & 3.6 & 89 & 135 \\
\hline 8 & 1.6 & 40 & 111 \\
\hline Total & 27.1 & & \\
\hline Average & & 85 & 212 \\
\hline
\end{tabular}

$115 \%$ of cycle iodine remains.

Assumed no iodine loss for calculations. 
TABLE A.27. Iodine-Loading Characteristics for AgZ Bed 2, Cycle 8, Stripping Stage

\begin{tabular}{|c|c|c|c|}
\hline $\begin{array}{l}\text { Agz } \\
\text { Bed } \\
\text { Segment } \\
\end{array}$ & $\begin{array}{c}\text { Cycle } \\
\text { Loading, } \\
\text { g I }\end{array}$ & $\begin{array}{l}\text { Cycle } \\
\text { Loading, } \\
\text { mg I/g AgZ }\end{array}$ & $\begin{array}{l}\text { Total } \\
\text { Loading } \\
\text { mg I/g AgZ }\end{array}$ \\
\hline 1 & 0.00 & 0.0 & 144 \\
\hline 2 & 0.00 & 0.0 & 211 \\
\hline 3 & 0.52 & 13 & 191 \\
\hline 4 & 0.53 & 13 & 119 \\
\hline 5 & 1.5 & 36 & 125 \\
\hline 6 & 2.6 & 65 & 109 \\
\hline 7 & 2.2 & 54 & 87 \\
\hline 8 & 1.0 & 26 & 91 \\
\hline Total & 8.35 & & \\
\hline Average & & 26 & 140 \\
\hline
\end{tabular}

$30.6 \%$ of cycle iodine remains. 
TABLE A.28. Iodine-Loading Characteristics for Bed 2, Cycle 9, Loading Stage

\begin{tabular}{|c|c|c|c|}
\hline $\begin{array}{l}\mathrm{AgZ} \\
\text { Bed } \\
\text { Segment }\end{array}$ & $\begin{array}{c}\text { Cycle } \\
\text { Loading, } \\
\text { g I }\end{array}$ & $\begin{array}{l}\text { Cycle } \\
\text { Loading, } \\
\mathrm{mg} \mathrm{I} / \mathrm{g} \mathrm{Agz}\end{array}$ & $\begin{array}{l}\text { Total } \\
\text { Loading } \\
\mathrm{mg} \mathrm{I} / \mathrm{g} \mathrm{AgZ} \\
\end{array}$ \\
\hline 1 & 5.7 & 143 & 287 \\
\hline 2 & 3.3 & 82 & 293 \\
\hline 3 & 3.3 & 82 & 273 \\
\hline 4 & 3.2 & 79 & 198 \\
\hline 5 & 2.1 & 52 & 177 \\
\hline 6 & 1.2 & 29 & 138 \\
\hline 7 & 0.71 & 18 & 105 \\
\hline 8 & 0.00 & 0.0 & 74 \\
\hline Total & 19.4 & & \\
\hline Average & & 61 & 201 \\
\hline
\end{tabular}

TABLE A.29. Iodine-Loading Characteristics for Agz Bed 2, Cycle 9, Drying Stage

\begin{tabular}{|c|c|c|c|}
\hline $\begin{array}{l}\text { Agz } \\
\text { Bed } \\
\text { Segment } \\
\end{array}$ & $\begin{array}{c}\text { Cycle } \\
\text { Loading, } \\
\text { g I } \\
\end{array}$ & $\begin{array}{l}\text { Cycle } \\
\text { Loading, } \\
\text { mg I/g AgZ }\end{array}$ & $\begin{array}{l}\text { Total } \\
\text { Loading } \\
\mathrm{mg} \mathrm{I} / \mathrm{g} \mathrm{AgZ}\end{array}$ \\
\hline 1 & 0.97 & 24 & 168 \\
\hline 2 & 0.26 & 6 & 217 \\
\hline 3 & 0.00 & 0.0 & 186 \\
\hline 4 & 0.54 & 13 & 132 \\
\hline 5 & 0.19 & 5 & 130 \\
\hline 6 & 0.00 & 0.0 & 103 \\
\hline 7 & 0.25 & 6 & 94 \\
\hline 8 & 0.00 & 0.0 & 67 \\
\hline
\end{tabular}

Total 2.2

Average 
TABLE A.30. Iodine-Loading Characteristics for AgZ Bed 2, Cycle 9, Stripping Stage

\begin{tabular}{|c|c|c|c|}
\hline $\begin{array}{l}\mathrm{AgZ} \\
\text { Bed } \\
\text { Segment } \\
\end{array}$ & $\begin{array}{c}\text { Cycle } \\
\text { Loading, } \\
\text { g I }\end{array}$ & $\begin{array}{l}\text { Cycle } \\
\text { Loading, } \\
\text { mg I/g AgZ }\end{array}$ & $\begin{array}{l}\text { Total } \\
\text { Loading } \\
\mathrm{mg} \mathrm{I/g} \mathrm{AgZ}\end{array}$ \\
\hline 1 & 1.8 & 45 & 189 \\
\hline 2 & 0.00 & 0.0 & 208 \\
\hline 3 & 0.00 & 0.0 & 164 \\
\hline 4 & 0.00 & 0.0 & 101 \\
\hline 5 & 0.00 & 0.0 & 90 \\
\hline 6 & 0.00 & 0.0 & 78 \\
\hline 7 & 0.00 & 0.0 & 76 \\
\hline 8 & 0.42 & 11 & 77 \\
\hline Total & 2.22 & & \\
\hline Average & & 7 & 123 \\
\hline
\end{tabular}

$13.8 \%$ of cycle iodine remains. 
TABLE A.31. Iodine-Loading Characteristics for AgZ Bed 2, Cycle 10, Loading Stage

\begin{tabular}{|c|c|c|c|}
\hline $\begin{array}{l}\text { AgZ } \\
\text { Bed } \\
\text { Segment } \\
\end{array}$ & $\begin{array}{c}\text { Cycle } \\
\text { Loading, } \\
\text { g I }\end{array}$ & $\begin{array}{l}\text { Cycle } \\
\text { Loading, } \\
\mathrm{mg} \mathrm{I} / \mathrm{g} \text { AgZ }\end{array}$ & $\begin{array}{l}\text { Total } \\
\text { Loading } \\
\mathrm{mg} \mathrm{I} \mathrm{g} \text { AgZ }\end{array}$ \\
\hline 1 & 2.4 & 59 & 248 \\
\hline 2 & 3.0 & 75 & 283 \\
\hline 3 & 3.3 & 83 & 247 \\
\hline 4 & 2.8 & 70 & 171 \\
\hline 5 & 2.0 & 51 & 141 \\
\hline 6 & 1.1 & 27 & 105 \\
\hline 7 & 0.5 & 12 & 88 \\
\hline 8 & 0.04 & 1 & 78 \\
\hline
\end{tabular}

Total $\quad 15.2$

Average

47

170

TABLE A.32. Iodine-Loading Characteristics for AgZ Bed 2, Cycle 10, Drying Stage

\begin{tabular}{|c|c|c|c|}
\hline $\begin{array}{l}\text { Agz } \\
\text { Bed } \\
\text { Segment }\end{array}$ & $\begin{array}{c}\text { Cycle } \\
\text { Loading, } \\
\text { g I }\end{array}$ & $\begin{array}{l}\text { Cycle } \\
\text { Loading, } \\
\text { mg I/g AgZ }\end{array}$ & $\begin{array}{l}\text { Total } \\
\text { Loading } \\
\mathrm{mg} \mathrm{I/g} \mathrm{AgZ}\end{array}$ \\
\hline 1 & 1.1 & 26 & 215 \\
\hline 2 & 2.3 & 57 & 265 \\
\hline 3 & 2.6 & 65 & 229 \\
\hline 4 & 2.6 & 64 & 169 \\
\hline 5 & 2.2 & 55 & 145 \\
\hline 6 & 1.2 & 31 & 109 \\
\hline 7 & 0.68 & 17 & 92 \\
\hline 8 & 0.047 & 1 & 79 \\
\hline Total & 12.6 & & \\
\hline Average & & 40 & 162 \\
\hline
\end{tabular}

83.4\% of cycle iodine remains. 
TABLE A.33. Iodine-Loading Characteristics for AgZ Bed 2, Cycle 10, Stripping Stage

\begin{tabular}{|c|c|c|c|}
\hline $\begin{array}{l}\text { AgZ } \\
\text { Bed } \\
\text { Segment } \\
\end{array}$ & $\begin{array}{c}\text { Cycle } \\
\text { Loading, } \\
\text { g I } \\
\end{array}$ & $\begin{array}{l}\text { Cycle } \\
\text { Loading, } \\
\text { mg I/g AgZ }\end{array}$ & $\begin{array}{l}\text { Total } \\
\text { Loading } \\
\mathrm{mg} \mathrm{I/g} \mathrm{AgZ}\end{array}$ \\
\hline 1 & 1.2 & 31 & 220 \\
\hline 2 & 1.7 & 42 & 250 \\
\hline 3 & 1.1 & 27 & 191 \\
\hline 4 & 0.51 & 13 & 114 \\
\hline 5 & 0.080 & 2 & 92 \\
\hline 6 & 0.00 & 0.0 & 55 \\
\hline 7 & 0.00 & 0.0 & 46 \\
\hline 8 & 0.00 & 0.0 & 56 \\
\hline Total & 4.6 & & \\
\hline Average & & 14 & 137 \\
\hline
\end{tabular}

$30.4 \%$ of cycle iodine remains. 
TABLE A.34. Iodine Loading Characteristics for AgZ Bed 2, Cycle 11, Loading Stage

\begin{tabular}{|c|c|c|c|}
\hline $\begin{array}{c}\mathrm{AgZ} \\
\text { Bed } \\
\text { Segment } \\
\end{array}$ & $\begin{array}{c}\text { Cycle } \\
\text { Loading, } \\
\text { g I } \\
\end{array}$ & $\begin{array}{l}\text { Cycle } \\
\text { Loading, } \\
\text { mg I/g AgZ } \\
\end{array}$ & $\begin{array}{l}\text { Total } \\
\text { Loading } \\
\text { mg } \mathrm{I} / \mathrm{g} \mathrm{AgZ}\end{array}$ \\
\hline 1 & 1.3 & 33 & 253 \\
\hline 2 & 2.8 & 70 & 320 \\
\hline 3 & 3.8 & 95 & 286 \\
\hline 4 & 4.1 & 103 & 217 \\
\hline 5 & 3.1 & 78 & 170 \\
\hline 6 & 1.8 & 46 & 101 \\
\hline 7 & 1.2 & 30 & 77 \\
\hline 8 & 0.29 & 7 & 61 \\
\hline Total & 18.5 & & \\
\hline Average & & 58 & 195 \\
\hline
\end{tabular}

TABLE A.35. Iodine Loading Characteristics for AgZ Bed 2, Cycle 11, Drying Stage \#1

\begin{tabular}{|c|c|c|c|}
\hline $\begin{array}{l}\text { Agz } \\
\text { Bed } \\
\text { Segment }\end{array}$ & $\begin{array}{c}\text { Cycle } \\
\text { Loading, } \\
\text { g I } \\
\end{array}$ & $\begin{array}{l}\text { Cycle } \\
\text { Loading, } \\
\text { mg I/g Agz }\end{array}$ & $\begin{array}{l}\text { Total } \\
\text { Loading } \\
\mathrm{mg} \mathrm{I} / \mathrm{g} \mathrm{AgZ} \\
\end{array}$ \\
\hline $\begin{array}{l}1 \\
2 \\
3 \\
4 \\
5 \\
6 \\
7 \\
8\end{array}$ & $\begin{array}{l}1.5 \\
2.2 \\
3.1 \\
3.4 \\
3.4 \\
2.7 \\
1.6 \\
0.66\end{array}$ & $\begin{array}{l}38 \\
55 \\
77 \\
85 \\
84 \\
67 \\
41 \\
17\end{array}$ & $\begin{array}{r}268 \\
319 \\
288 \\
221 \\
198 \\
139 \\
98 \\
77\end{array}$ \\
\hline $\begin{array}{l}\text { Total } \\
\text { Average }\end{array}$ & 18.5 & 58 & 210 \\
\hline
\end{tabular}


TABLE A.36. Iodine Loading Characteristics for AgZ Bed 2, Cycle 11, Stripping Stage \#1

\begin{tabular}{|c|c|c|c|}
\hline $\begin{array}{l}\text { Agz } \\
\text { Bed } \\
\text { Segment } \\
\end{array}$ & $\begin{array}{c}\text { Cycle } \\
\text { Loading, } \\
\text { g I } \\
\end{array}$ & $\begin{array}{l}\text { Cycle } \\
\text { Loading, } \\
\mathrm{mg} \mathrm{I/g} \mathrm{AgZ}\end{array}$ & $\begin{array}{c}\text { Total } \\
\text { Loading } \\
\text { mg I/g AgZ }\end{array}$ \\
\hline 1 & 0.00 & 0.0 & 11 \\
\hline 2 & 0.00 & 0.0 & 66 \\
\hline 3 & 0.00 & 0.0 & 90 \\
\hline 4 & 0.00 & 0.0 & 73 \\
\hline 5 & 0.00 & 0.0 & 87 \\
\hline 6 & 0.46 & 12 & 67 \\
\hline 7 & 0.57 & 14 & 60 \\
\hline 8 & 0.32 & 8 & 64 \\
\hline Total & 1.35 & & \\
\hline Average & & 34 & 65 \\
\hline
\end{tabular}

$7.35 \%$ of cycle iodine remains.

TABLE A.37. Iodine Loading Characteristics for AgZ Bed 2, Cycle 11, Drying Stage \#2

\begin{tabular}{|c|c|c|c|}
\hline $\begin{array}{l}\text { Agz } \\
\text { Bed } \\
\text { Segment } \\
\end{array}$ & $\begin{array}{c}\text { Cycle } \\
\text { Loading, } \\
\text { g I }\end{array}$ & $\begin{array}{l}\text { Cycle } \\
\text { Loading, } \\
\text { mg I/g AgZ }\end{array}$ & $\begin{array}{l}\text { Total } \\
\text { Loading } \\
\text { mg I/g AgZ }\end{array}$ \\
\hline 1 & 0.00 & 0.0 & 10 \\
\hline 2 & 0.00 & 0.0 & 14 \\
\hline 3 & 0.00 & 0.0 & 20 \\
\hline 4 & 0.00 & 0.0 & 16 \\
\hline 5 & 0.00 & 0.0 & 39 \\
\hline 6 & 0.00 & 0.0 & 50 \\
\hline 7 & 0.00 & 0.0 & 44 \\
\hline 8 & 0.42 & 11 & 67 \\
\hline
\end{tabular}

Total $\quad 0.42$

Average

$2.3 \%$ of cycle iodine remains. 
TABLE A.38. Iodine Loading Characteristics for AgZ Bed 2, Cycle 11, Stripping Stage \#2

\begin{tabular}{|c|c|c|c|}
\hline $\begin{array}{l}\text { Agz } \\
\text { Bed } \\
\text { Segment } \\
\end{array}$ & $\begin{array}{c}\text { Cycle } \\
\text { Loading, } \\
\text { g I } \\
\end{array}$ & $\begin{array}{l}\text { Cycle } \\
\text { Loading, } \\
\text { mg I/g AgZ }\end{array}$ & $\begin{array}{l}\text { Total } \\
\text { Loading } \\
\mathrm{mg} \mathrm{I/g} \mathrm{AgZ}\end{array}$ \\
\hline 1 & 0.00 & 0.0 & 8 \\
\hline 2 & 0.00 & 0.0 & 10 \\
\hline 3 & 0.00 & 0.0 & 9 \\
\hline 4 & 0.00 & 0.0 & 7 \\
\hline 5 & 0.00 & 0.0 & 13 \\
\hline 6 & 0.00 & 0.0 & 25 \\
\hline 7 & 0.061 & 2 & 45 \\
\hline 8 & 0.64 & 16 & 72 \\
\hline
\end{tabular}

Total

0.70

Average

2

24

$3.8 \%$ of cycle iodine remains.

TABLE A.39. Iodine Loading Characteristics for AgZ Bed 2, Cycle 11, Stripping Stage \#3

\begin{tabular}{|c|c|c|c|}
\hline $\begin{array}{l}\text { Agz } \\
\text { Bed } \\
\text { Segment } \\
\end{array}$ & $\begin{array}{c}\text { Cycle } \\
\text { Loading, } \\
\text { g I } \\
\end{array}$ & $\begin{array}{l}\text { Cycle } \\
\text { Loading, } \\
\mathrm{mg} \mathrm{I} / \mathrm{g} \mathrm{AgZ}\end{array}$ & $\begin{array}{l}\text { Total } \\
\text { Loading } \\
\text { mg I/g AgZ }\end{array}$ \\
\hline 1 & 0.013 & 0.3 & 8 \\
\hline 2 & 0.010 & 0.2 & 10 \\
\hline 3 & 0.00 & 0.0 & 9 \\
\hline 4 & 0.00 & 0.0 & 6 \\
\hline 5 & 0.00 & 0.0 & 11 \\
\hline 6 & 0.00 & 0.0 & 21 \\
\hline 7 & 0.15 & 4 & 48 \\
\hline 8 & 0.54 & 13 & 70 \\
\hline
\end{tabular}

Total

0.70

Average

2

21

$3.8 \%$ of cycle iodine remains. 
TABLE A.40. Iodine Loading Characteristics for Agz Bed 2, Cycle 12, Loading Stage

\begin{tabular}{|c|c|c|c|}
\hline $\begin{array}{l}\text { AgZ } \\
\text { Bed } \\
\text { Segment } \\
\end{array}$ & $\begin{array}{c}\text { Cycle } \\
\text { Loading, } \\
\text { g I } \\
\end{array}$ & $\begin{array}{l}\text { Cycle } \\
\text { Loading, } \\
\mathrm{mg} \mathrm{I} / \mathrm{g} \mathrm{AgZ} \\
\end{array}$ & $\begin{array}{l}\text { Total } \\
\text { Loading } \\
\mathrm{mg} \mathrm{I} \mathrm{g} \mathrm{AgZ} \\
\end{array}$ \\
\hline 1 & 4.8 & 120 & 128 \\
\hline 2 & 5.8 & 146 & 156 \\
\hline 3 & 6.5 & 162 & 171 \\
\hline 4 & 5.7 & 142 & 148 \\
\hline 5 & 4.1 & 102 & 113 \\
\hline 6 & 2.1 & 53 & 74 \\
\hline 7 & 0.77 & 19 & 67 \\
\hline 8 & 0.23 & 6 & 75 \\
\hline Total & 30.0 & & \\
\hline Average & & 94 & 116 \\
\hline
\end{tabular}

TABLE A.41. Iodine Loading Characteristics for AgZ Bed 2, Cycle 12, Drying Stage

\begin{tabular}{|c|c|c|c|}
\hline $\begin{array}{l}\mathrm{Agz} \\
\text { Bed } \\
\text { Segment } \\
\end{array}$ & $\begin{array}{c}\text { Cycle } \\
\text { Loading, } \\
\text { g I } \\
\end{array}$ & $\begin{array}{l}\text { Cycle } \\
\text { Loading, } \\
\text { mg I/g AgZ }\end{array}$ & $\begin{array}{l}\text { Total } \\
\text { Loading } \\
\mathrm{mg} \mathrm{I} / \mathrm{g} \mathrm{AgZ} \\
\end{array}$ \\
\hline 1 & 3.7 & 92 & 101 \\
\hline 2 & 5.2 & 131 & 141 \\
\hline 3 & 5.8 & 145 & 154 \\
\hline 4 & 4.7 & 118 & 124 \\
\hline 5 & 3.5 & 88 & 100 \\
\hline 6 & 1.6 & 41 & 62 \\
\hline 7 & 0.64 & 16 & 64 \\
\hline 8 & 0.014 & 0.4 & 70 \\
\hline Total & 25.3 & & \\
\hline Average & & 79 & 102 \\
\hline
\end{tabular}

$84.2 \%$ of cycle iodine remains. 
TABLE A.42. Iodine Loading Characteristics for AgZ Bed 2, Cycle 12, Stripping Stage \#1

\begin{tabular}{|c|c|c|c|}
\hline $\begin{array}{l}\text { Agz } \\
\text { Bed } \\
\text { Segment } \\
\end{array}$ & $\begin{array}{l}\text { Cycle } \\
\text { Loading, } \\
\text { g I } \\
\end{array}$ & $\begin{array}{l}\text { Cycle } \\
\text { Loading, } \\
\mathrm{mg} \mathrm{I/g} \mathrm{AgZ}\end{array}$ & $\begin{array}{l}\text { Total } \\
\text { Loading } \\
\mathrm{mg} \mathrm{I/g} \mathrm{AgZ} \\
\end{array}$ \\
\hline 1 & 3.4 & 85 & 94 \\
\hline 2 & 5.4 & 134 & 144 \\
\hline 3 & 5.9 & 147 & 156 \\
\hline 4 & 3.7 & 92 & 98 \\
\hline 5 & 3.9 & 96 & 108 \\
\hline 6 & 1.8 & 45 & 66 \\
\hline 7 & 0.84 & 21 & 68 \\
\hline 8 & 0.44 & 11 & 81 \\
\hline Total & 25.3 & & \\
\hline Average & & 79 & 102 \\
\hline
\end{tabular}

$84.1 \%$ of cycle iodine remains.

TABLE A.43. Iodine Loading Characteristics for AgZ Bed 2, Cycle 12, Stripping Stage \#2

\begin{tabular}{|c|c|c|c|}
\hline $\begin{array}{l}\mathrm{Agz} \\
\text { Bed } \\
\text { Segment } \\
\end{array}$ & $\begin{array}{c}\text { Cycle } \\
\text { Loading, } \\
\text { g I }\end{array}$ & $\begin{array}{l}\text { Cycle } \\
\text { Loading, } \\
\text { mg I/g AgZ }\end{array}$ & $\begin{array}{l}\text { Total } \\
\text { Loading } \\
\mathrm{mg} \mathrm{I/g} \mathrm{AgZ}\end{array}$ \\
\hline 1 & 3.6 & 90 & 99 \\
\hline 2 & 5.2 & 130 & 140 \\
\hline 3 & 4.1 & 103 & 112 \\
\hline 4 & 2.1 & 52 & 58 \\
\hline 5 & 0.54 & 14 & 25 \\
\hline 6 & 0.11 & 3 & 24 \\
\hline 7 & 0.00 & 0.0 & 40 \\
\hline 8 & 0.22 & 5 & 75 \\
\hline Total & 15.9 & & \\
\hline Average & & 50 & 72 \\
\hline
\end{tabular}

$53.0 \%$ of cycle iodine remains. 
TABLE A.44. Iodine Loading Characteristics for AgZ Bed 2, Cycle 12, Stripping Stage \#3

\begin{tabular}{|c|c|c|c|}
\hline $\begin{array}{l}\mathrm{AgZ} \\
\text { Bed } \\
\text { Segment } \\
\end{array}$ & $\begin{array}{c}\text { Cycle } \\
\text { Loading, } \\
\text { g I } \\
\end{array}$ & $\begin{array}{l}\text { Cycle } \\
\text { Loading, } \\
\mathrm{mg} \mathrm{I} / \mathrm{g} \text { AgZ } \\
\end{array}$ & $\begin{array}{l}\text { Total } \\
\text { Loading } \\
\mathrm{mg} \mathrm{I/g} \mathrm{AgZ}\end{array}$ \\
\hline 1 & 6.1 & 152 & 161 \\
\hline 2 & 4.0 & 100 & 110 \\
\hline 3 & 3.8 & 95 & 104 \\
\hline 4 & 1.2 & 31 & 37 \\
\hline 5 & 0.090 & 2 & 14 \\
\hline 6 & 0.00 & 0.0 & 12 \\
\hline 7 & 0.00 & 0.0 & 35 \\
\hline 8 & 0.24 & 6 & 66 \\
\hline Total & 15.5 & & \\
\hline Average & & 48 & 67 \\
\hline
\end{tabular}

$51.6 \%$ of cycle iodine remains.

TABLE A.45. Iodine Loading Characteristics for AgZ Bed 2, Cycle 12, Stripping Stage \#4

\begin{tabular}{|c|c|c|c|}
\hline $\begin{array}{c}\text { AgZ } \\
\text { Bed } \\
\text { Segment } \\
\end{array}$ & $\begin{array}{c}\text { Cycle } \\
\text { Loading, } \\
\text { g I } \\
\end{array}$ & $\begin{array}{l}\text { Cycle } \\
\text { Loading, } \\
\mathrm{mg} \mathrm{I/g} \mathrm{AgZ}\end{array}$ & $\begin{array}{c}\text { Total } \\
\text { Loading, } \\
\mathrm{mg} \mathrm{I} / \mathrm{g} \mathrm{AgZ}\end{array}$ \\
\hline 1 & 3.23 & 81 & 89 \\
\hline 2 & 3.74 & 94 & 104 \\
\hline 3 & 2.46 & 62 & 70 \\
\hline 4 & 0.35 & 9 & 15 \\
\hline 5 & 0.14 & 4 & 15 \\
\hline 6 & 0 & 0 & 0 \\
\hline 7 & 0 & 0 & 0 \\
\hline 8 & 0 & 0 & 57 \\
\hline
\end{tabular}

Total $\quad 10.2$ 


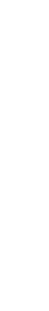


No. of

Copies

OFFSITE

27 DOE Technical Information Center

R. E. Cunningham

Office of Nuclear Safety

Materials and Safeguards

Room 562

Nuclear Regulatory Commission

7915 Eastern Avenue

Silver Springs, MD 20555

3 Division of Waste Management

Nuclear Regulatory Commission

Washington, DC 20910

Attn: J. B. Martin

D. B. Rohrer

R. D. Smith

Materials Section Leader

High Level Waste Licensing Branch

Nuclear Regulatory Commission

Washington, D. C. 20555

W. E. Mott

DOE Division of Environmental

Control Technology

EV-13, GTN

Washington, D. C. 20545

14 DOE Nuclear Waste Management and

Fuel Cycle Programs

NE30, GTN

Washington, D. C. 20545

Attn: W. W. Ballard

F. E. Coffman

C. R. Cooley

H. Feinroth

C. H. George

0 . Gormley

M. J. Lawrence

J. A. Leary

W. H. McVey

S. Meyers

A. F. Perge

R. W. Ramsey, Jr.

J. A. Turi

R. D. Walton
PNL -4490

UC-70

\section{DISTRIBUTION}

No. of

Copies

8 DOE Office of Defense Waste and Byproducts Management

DP-12, GTN

Washington, DC 20545

ATTN: A. A. Camacho

G. H. Daly

J. E. Dieckhoner

J. Jicha

D. J. McGoff

G. Dertel

A. L. Taboas

V. G. Trice

Environmental Protection Agency

Technological Assessment Division (AW-559)

Office of Radiation Programs

Washington, DC 20460

S. A. Mann

DOE Chicago Operations and

Region Office

Argonne, IL 60439

J. 0. Neff

DOE Columbus Program Office

505 King Avenue

Columbus, $\mathrm{OH} 43201$

4 DOE Idaho Operations Office

505 Second Street

Idaho Falls, ID 83401

Attn: J. P. Hamric

S. Vorndran

J. B. Whitsett

M. A. Widmayer

Office of the Assistant Manager for Energy Research and Development DOE Oak Ridge Operations Office P. 0. Box E

Oak Ridge, TN 37830

3 DOE Savannah River Operations Office P.0. Box A

Aiken, SC 29801

Attn: E. S. Goldberg

T. B. Hindman

R. P. Whitfield 
No. of

Copies

R. Y. Lowrey

DOE Albuquerque Operations Office P.0. Box 5400

Albuquerque, NM 87185

S. G. Harbinson

DOE San Francisco Operations

Office

1333 Broadway

Oakland, CA 94612

W. F. Holcomb

National Institute of Health

Radiation Safety Branch

Building 21

Bethesda, MD 20205

2 Allied-General Nuclear Services

P. 0. Box 847

Barnwel1, SC 29812

ATTN: J. A. Buckham

A. Williams

3 Argonne National Laboratory

9700 South Cass Avenue

Argonne, IL 60439

ATTN: J. H. Kittel

L. J. Jardine

M. J. Steindler/-

L. E. Trevorrow

10 Battelle Memorial Institute

505 King Avenue

Columbus, $\mathrm{OH} 43201$

ATTN: S. H. Basham

A. Brandstetter

W. Carbiener

N. E. Carter

J. 0 . Duguid

S. Goldsmith

P. L. Hofmann

M. Kehnemuyi

J. F. Kircher

B. Rawles

2 EG\&G Idaho, Inc.

P.0. Box 1625

Idaho Fal1s, ID 83415

ATTN: G. B. Levin

R. L. Tallman
No. of

Copies

\author{
R. Williams \\ Electric Power Research Institute \\ 3412 Hillview Avenue \\ P. 0. Box 10412 \\ Palo Alto, CA 94304
}

4 Exxon Nuclear Idaho

P.0. Box 2800

Idaho Falls, ID 83401

ATTN: R. A. Brown

J. D. Christian

D. L. Condotta

T. R. Thomas

Los Alamos National Laboratory

P. 0. Box 1663

Los Alamos, NM 87544

7 Oak Ridge National Laboratory

P.0. Box X

Oak Ridge, TN 37830

ATTN: R. E. Bl anco

J. 0. Blomeke

W. D. Burch

A. G. Croff

D. E. Ferguson

G. L. Haag

R. S. Lowrie

T. H. Row

7 E. I. duPont deNemours \& Co. Inc. Savannah River Laboratory

Aiken, SC 29801

ATTN: H. H. Baker

M. D. Boersma

J. L. Crandal 1

S. D. Harris

D. L. Mc Intosh

S. Mirshak

S. W. O'Rear

E. Vejvoda

Rockwell International

Rocky Flats Plant

P. 0. Box 464

Golden, CO 80401 
R. G. Barnes

General Electric Company

175 Curtner Avenue

(M/C 160)

San Jose, CA 95125

L. H. Brooks

Gulf Energy and Environmental Systems

P. 0. Box 81608

San Diego, CA 92138

J. L. Larocca, Chairman

Energy Research and Development Authority

Empire State Plaza

Albany, NY 12223

2 Lawrence Livermore Laboratory

P. 0. Box 808

Livermore, CA 94550

ATTN: J. H. Campbel1

W. G. Sutliff

4 Sandia Laboratories

Albuquerque, NM 87185

ATTN: D. R. Anderson

0 . E. Jones

R. G. Kepler

W. Weart

J. W. Bartlett

The Analytic Sciences Corp.

6 Jacob Way

Reading, MA 01867

W. A. Freeby

Bechtel Group, Inc.

Fifty Beale Street

P. 0. Box 3965

San Francisco, CA 94119

J. R. Potter

Chem-Nuclear Systems, Inc.

P. 0. Box 1866

Bellevue, WA 98009

R. G. Post

College of Engineering

University of Arizona

Tucson, AZ 85721
No. of

Copies

L. L. Hench

Dept. of Materials Science and Engineering

University of Florida

Gainesville, FL 32611

H. Palmour III

2140 Burlington Engineering Laboratories

North Carolina State University

Raleigh, NC 27607

W. Tope

Westinghouse Electric Corporation

Penn Center, Building 2

Box 355

Pittsburgh, PA 15230

R. Roy

202 Materials Research Laboratory

University Park, PA 16802

F. K. Pittman

3508 Sagecrest Terrace

Ft. Worth, TX 76109

ONSITE

6 DOE Richland Operations Office

E. A. Bracken

R. D. Gerton

H. E. Ransom

J. J. Schreiber (2)

M. W. Shupe

21 Rockwe11 Hanford Operations

H. Babad

J. L. Deichman

L. Jensen

R. G. Johnson

J. 0. Honeyman

J. E. Kinzer

E. J. Kosiancic

M. P. Larson

G. G. Pitts

I. E. Reep

J. Reser

J. H. Roecker

J. S. Schoefield 
No. of

Copies

W. W. Schulz

R. E. Vanderlock

R. Watson

J. R. Wetch

D. G. Wilkins

D. D. Wodrich

G. D. Wright

File copy

UNC United Nuclear Industries

F. H. Bouse, Document Control

T. E. Dabrowski,

Westinghouse Hanford Company
A. G. Blasewitz

R. E. Lerch

\section{Pacific Northwest Laboratory}

W. F. Bonner

F. P. Brauer

L. A. Bray

L. L. Burger (15)

D. B. Cearlock

T. D. Chikalla

F. H. Dove

H. Drucker

C. E. Elderkin

C. R. Hann

A. J. Haverfield

0. F. Hill

J. H. Jarrett

A. B. Johnson, Jr.

M. R. Kreiter

L. T. Lakey

S. F. Liebetrau

R. C. Liikala

R. P. Marshall

J. L. McElroy

R. W. McKee

J. E. Mendel

J. E. Minor

I. C. Nelson

J. M. Nielsen/R. W. Perkins

R. E. Nightingale

D. E. Olesen

A. M. Platt

J. V. Robinson

W. A. Ross/R. D. Nelson
J. M. Rusin

R. D. Scheele (15)

J. K. Soldat

A. M. Sutey

J. L. Swanson

G. L. Tingey

R. P. Turcotte

C. M. Unruh

H. H. Van Tuyl

B. E. Vaughn

E. C. Watson

E. J. Wheelwright

W. R. Wiley

Technical Information (5)

Publishing Coordination (2) 